\title{
ANODES FOR SOFC: REVIEW OF MATERIAL SELECTION, INTERFACE AND ELECTROCHEMICAL PHENOMENA
}

\author{
Marina Curi ${ }^{\mathrm{a}, *,(1)}$, Eduardo da R. Silva ${ }^{\mathrm{b}, \mathrm{c}}$, José Geraldo de M. Furtado ${ }^{\mathrm{c}}$, Helen C. Ferraz ${ }^{\mathrm{b}}$ and Argimiro R. Secchi $^{\mathrm{b}}$ \\ ${ }^{a}$ Escola de Química e Alimentos, Universidade Federal do Rio Grande, 96203-000 Rio Grande - RS, Brasil \\ ${ }^{\mathrm{b} C e n t r o}$ de Tecnologia, Universidade Federal do Rio de Janeiro, 21941-972 Rio de Janeiro - RJ, Brasil \\ ${ }^{\mathrm{c}}$ Centro de Pesquisa em Energia Elétrica, 21941-911 Rio de Janeiro - RJ, Brasil
}

Recebido em 17/06/2020; aceito em 27/08/2020; publicado na web em 08/10/2020

\begin{abstract}
This paper presents a comprehensive interface and electrochemical phenomena review of different anodes for SOFC. In this way, it was possible to select some mixed electronic and ionic conductor materials alternatives to the conventional anode, Ni-YSZ conductor. New materials must present a satisfactory electronic and ionic conductivity at intermediate temperatures, be able to operate under different types of hydrocarbon fuels without deactivation, present stability under redox cycles and thermal expansion compatible with the other materials. Among all new materials, $\mathrm{Sr}_{0.86} \mathrm{Y}_{0.08} \mathrm{TiO}_{3}$, a Y-doped strontium titanate (YST), presented the highest measured conductivity, of $82 \mathrm{~S} \mathrm{~cm}^{-1}$ at $800{ }^{\circ} \mathrm{C}$. In addition, this material showed excellent stability time and coefficient of thermal expansion compatible with materials used as cathode, strontium-doped lanthanum manganite and electrolyte, yttria stabilized zirconia. $\mathrm{SrTiO}_{3}$ (ST) compounds synthesized by solid-state reaction method, calcined, and sintered to obtain undoped (ST), 4\% (YST04) and 8\% (YST08) of Y-dopant and as a heterojunction with yttria-stabilized zirconia (YST08/YSZ). It was observed that calcination under $\mathrm{Ar} / 5 \% \mathrm{H}_{2}$ atmosphere has increased the dopant maximum concentration in the $\mathrm{SrTiO}_{3}$ cubic crystal structure when compared to inert atmosphere. When the $\mathrm{Y}$ solubility limit was exceeded, a pyrochlore phase $\mathrm{Y}_{2} \mathrm{Ti}_{2} \mathrm{O}_{7}$ was formed on the intergranular region due to the deficiency of oxygen vacancies, especially in the presence of inert atmosphere.
\end{abstract}

Keywords: anode; interfacial phenomena; MIEC; SOFC.

\section{INTRODUCTION}

One of the main characteristics that affect solid oxide fuel cell (SOFC) performance is the structure of its electrodes (anode and cathode). Such characteristics are determined by the type of the structure utilized and its manufacturing process. Moreover, the electrochemical reactions that occur on the anode surface and on the interface of anode/electrolyte are different from other heterogeneous reactions. ${ }^{1}$ Thus, it is necessary to study how the anode behaves on microscopic and nanoscopic scales.

For more than forty years, Ni-YSZ cermet composites have been the main anode applied to SOFCs due to their excellent catalytic activity with hydrogen fuel, high electronic conductivity, ${ }^{2}$ reasonable ionic conductivity at high temperature, stability under the conditions of SOFC operations and relatively low manufacturing cost. This material has shown a satisfactory performance when compared to many other applied cermets such as $\mathrm{Ru} / \mathrm{ZrO} 2, \mathrm{Mg}$-YSZ, and pure $\mathrm{Ni}$. In this cermet conventional anode, the chemical reaction occurs on a three-phase boundary (3PB) defined as an interface composed by an oxygen-ion conductor phase YSZ (electrolyte), an electronic conductor phase (Ni metal) and a fuel gas phase. If the oxygen-ions or the fuel gas molecules do not reach the reaction site, or the electrons cannot be removed from the site, then the $3 \mathrm{~PB}$ is not able to contribute to the good performance of the SOFC (see Figure 1).

However, there are many limitations to the use of Ni-YSZ as an anodic material, mainly including a $\mathrm{Ni}$ agglomeration in a long-term

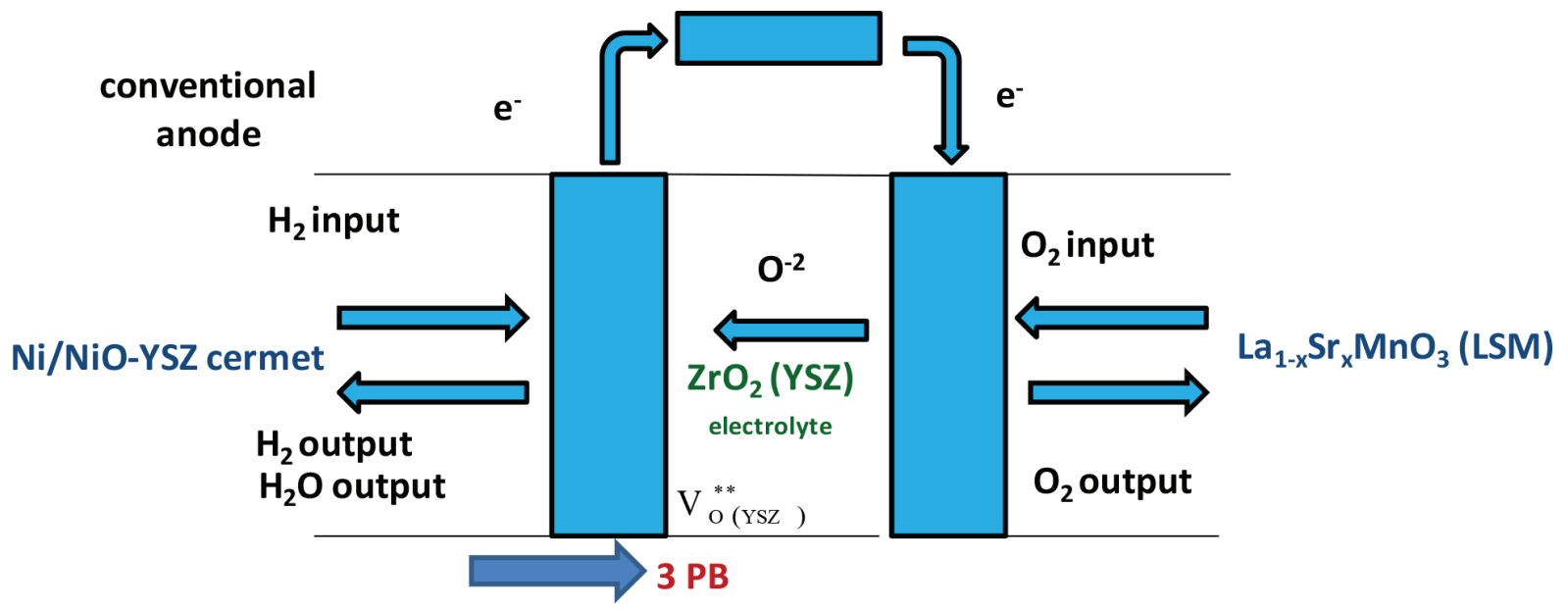

Figure 1. Simplified scheme of a SOFC applying conventional anode 
operation and the formation of carbon deposits with the breaking of the $\mathrm{C}-\mathrm{C}$ bond with the use of hydrocarbons. $\mathrm{Ni}$ is an excellent catalyst; therefore, carbon is deposited on the $\mathrm{Ni}$ surface, diffusing the $\mathrm{Ni}$ particle structure, and leading to the formation of carbon filaments, ${ }^{3}$ bringing the impossibility to operate using hydrocarbon fuels.

In this sense, in mixed ionic and electronic conductors (MIEC), charge carriers are combined in one single phase. In this type of material, ionic conductivity can be one order of magnitude higher than in conventional materials as YSZ, which allows decreasing the operation temperature, improving the SOFC performance and durability, as well as, making it possible to reduce the manufacturing costs of this fuel cell. Moreover, these materials can extend the active electrochemical regions for whole electrode surface. MIEC performs both as catalyst and as electrons and ions carrier. The electrochemical reactions are not restricted to the conductor interface but can occur along the entire surface. ${ }^{4}$

Comparing Figure 1 with Figure 2, it can be noted that the oxygen vacancy region, using MIEC as an anode, is not only restricted to the anode/electrolyte interfacial region $\mathrm{V}_{\mathrm{O}(\mathrm{Ysz})}^{* *}$, but it is also present along the anode thickness of $\left(1_{\mathrm{a}}\right) \mathrm{V}_{\mathrm{O}(\mathrm{MIEC})}^{* *}$.

Figures 3 and 4 present micrographs of a potential material composed by $8 \%$ Y-doped $\mathrm{SrTiO}_{3}$. It is possible to notice a welldefined grain boundary with an efficient interface formation between YSZ and YST08 grains, showing that both are compatible with no physical segregation. Another important characteristic shown in the structure is the possibility of assembling samples with porosity among $20-40 \%$. In $8 \%$ Y-doped $\mathrm{SrTiO}_{3}$, porosity of $36.7 \pm 7.2 \%$ was found using $10 \% \mathrm{w} / \mathrm{w}$ of graphite before the sintering process. It is possible to observe that there is wide pore network, this feature is important to maintain the fuel gas diffusivity and the product exhaustion.

\section{SOFC anodes}

The YSZ grains constitute a support which acts as an inhibitor to the sintering of Ni powders during the SOFC operation, since the $\mathrm{Ni}$ thermal expansion coefficient (TEC), $16.9 \times 10^{-6} \mathrm{~K}^{-1}$, is higher than that of YSZ $\left(11 \times 10^{-6} \mathrm{~K}^{-1}\right)$. Therefore, the use of YSZ makes the TEC of the Ni/YSZ composite close to the other components of the SOFC. Additionally, due to the high electronic conductivity of $\mathrm{Ni}$, the ionic conductivity of the material is improved, since the proportion in volume percentage of $\mathrm{Ni}$ and YSZ ranges from 35:65 to 55:45, providing a conductivity of the material ranging from 0.1 to $10^{3} \mathrm{~S} \mathrm{~cm}^{-1}$.

The poisoning of the $\mathrm{Ni} / \mathrm{YSZ}$ anode by impurities containing sulfur in the $\mathrm{H}_{2}$ current has been studied using electrochemical impedance spectroscopy (EIS) and direct current (DC) polarization method. There are models that describe the loss of electrode performance due to the presence of $\mathrm{H}_{2} \mathrm{~S}$, however, according to Matsuaki and Yasuda, ${ }^{6}$ the exact mechanism responsible for the loss of performance

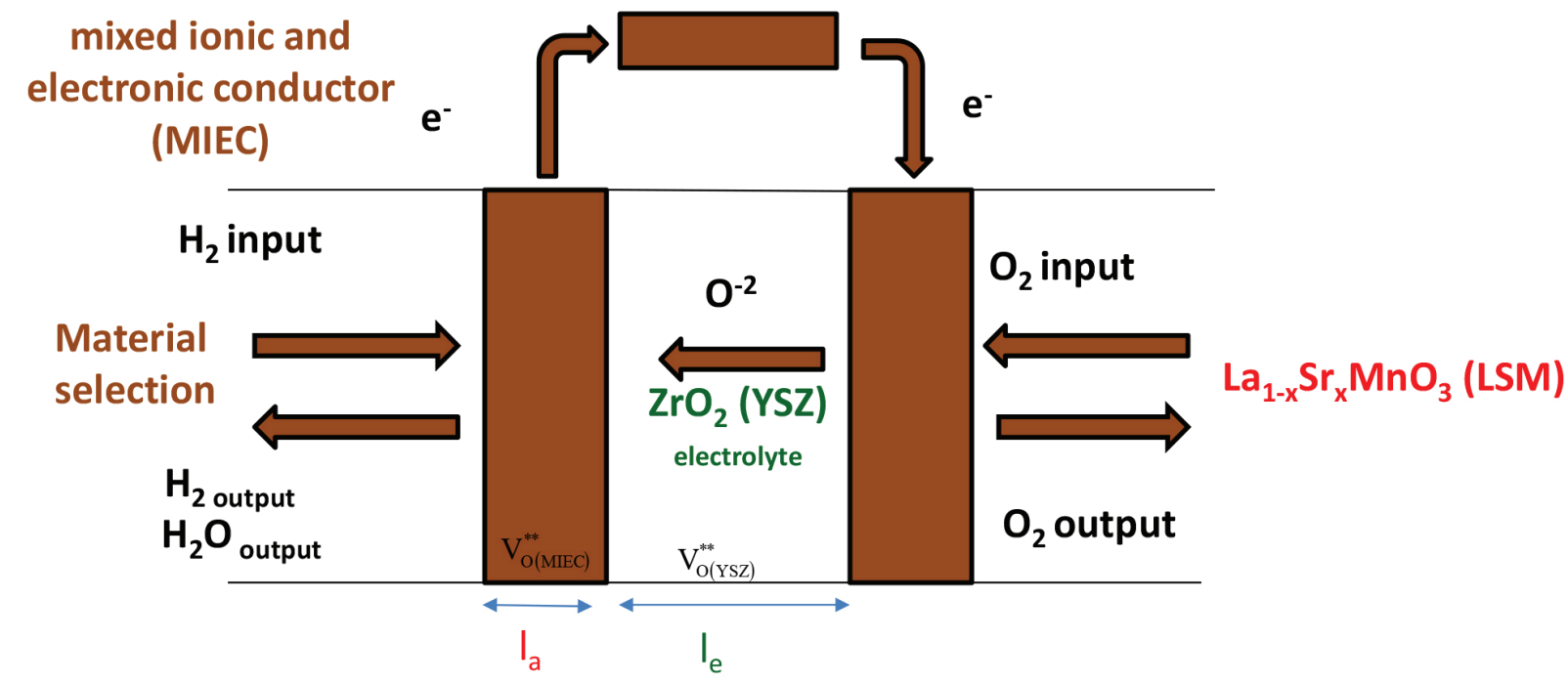

Figure 2. Simplified scheme of a SOFC applying MIEC anode

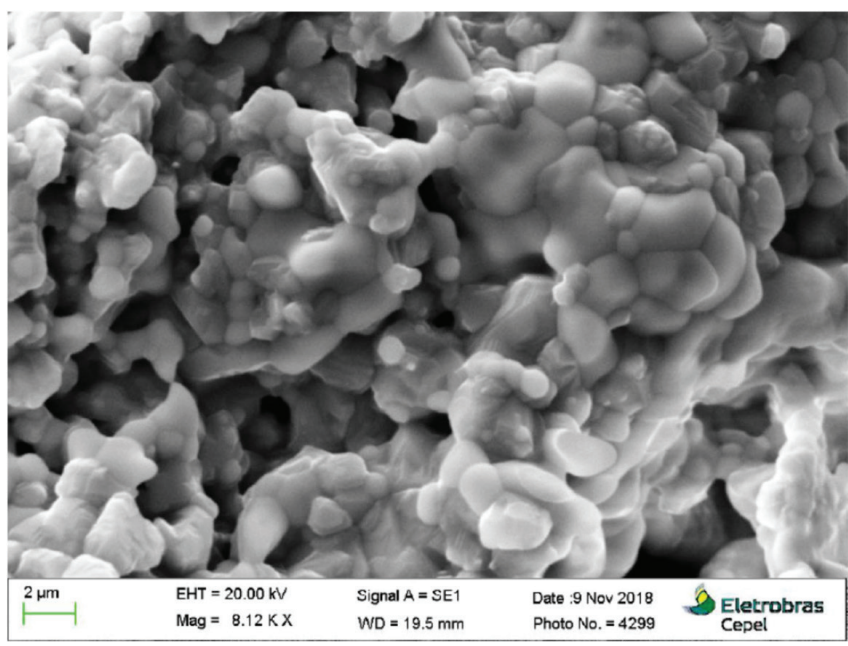

Figure 3. YSZ/YSTO8 heterojunction using graphite - porosity $27.01 \%$

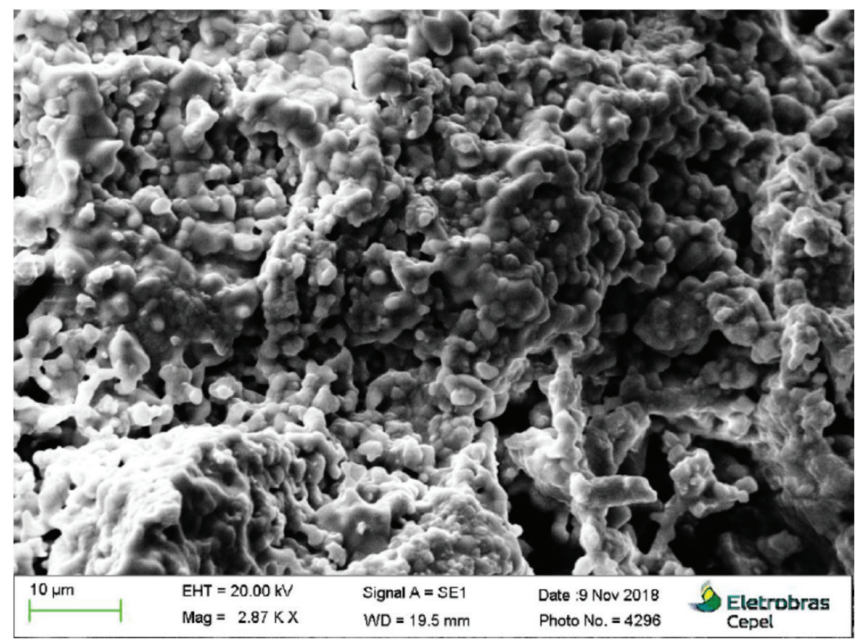

Figure 4. YSZ/YSTO8 heterojunction using graphite - porosity $38.82 \%$ 
is not clearly defined yet due to the lack of experimental data in these specific conditions. The polarization resistance and electrode overpotential increased when the $\mathrm{H}_{2} \mathrm{~S}$ concentration exceeded 0.05 , 0.5 and $2 \mathrm{ppm}$ at 1023,1173 and $1273 \mathrm{~K}$, respectively. The time required for the sulfide to influence saturation was approximately 3 hours and 20 minutes, 2 hours and 30 minutes, and 1 hour at 1023, 1173 and $1273 \mathrm{~K}$, respectively. Although there are many benefits in reducing the operating temperature, it must be considered that at low temperatures the sulfides can be strongly adsorbed on the surface of the anode electrode of the SOFC and degrade the resistance against impurities (sulfides) reducing the conductivity due to microstructural degradation. This was later confirmed by Lussier et al. ${ }^{7}$ who showed a mechanism that reveals the degeneration of $\mathrm{Ni} / \mathrm{YSZ}$ and Ni/GDC anodes exposed to $\mathrm{H}_{2} \mathrm{~S}$, thus compromising the electrical conductivity of the anode and, consequently, the SOFC performance.

According to Flores and Rodríguez ${ }^{8}$ and Tarôco et al., ${ }^{5}$ in general, the anode must meet the following requirements:

- High electronic conductivity $\left(\sim 100 \mathrm{~S} \mathrm{~cm}^{-1}\right)$;

- Chemical stability at low oxygen partial pressures $\left(10^{-20}\right.$ bar $)$ and with other fuel cells (FC) components (electrolyte and interconnector);

- High catalytic activity for oxidation reaction of the selected fuel gas;

- Coefficient of thermal expansion similar to other components;

- Ability to avoid carbon deposition;

- Optimization of the electric transport microstructure (ionic + electronic);

- Stability in reducing environment;

- It must be thin enough to transport mass and minimize ohmic losses, but also have a certain thickness to distribute the electric current;

- Adequate porosity (20-40\%) for fuel supply and removal of the product from the reaction.

- The anode, besides providing the electrochemical reaction of oxidation of the fuel, must also transfer the electrons. The oxygen anions migrate, through the electrolyte, from the cathode to the anode, due to the potential difference, where they are consumed by the oxidation of the fuel according to the following reactions: ${ }^{9}$

$$
\begin{gathered}
\mathrm{H}_{2}+\mathrm{O}^{-2} \rightarrow 2 \mathrm{e} \\
\mathrm{CO}+\mathrm{O}^{-2} \rightarrow 2 \mathrm{e} \\
\mathrm{C}_{\mathrm{n}} \mathrm{H}_{(2 \mathrm{n}+2)}+(3 \mathrm{n}+1) \mathrm{O}^{-2} \rightarrow \mathrm{nCO}_{2}+(\mathrm{n}+1) \mathrm{H}_{2} \mathrm{O}+(6 \mathrm{n}+2) \mathrm{e}
\end{gathered}
$$

As showed in Equations 1 and 2, two electrons are transferred for each mole of water and $\mathrm{CO}_{2}$ formed, respectively. The molar flow rate of water $\left(\mathrm{R}_{\mathrm{H} 2 \mathrm{O}}\right)$ and $\mathrm{CO}_{2}\left(\mathrm{R}_{\mathrm{CO} 2}\right)$ formation can be determined by Faraday's Law (Equations 4 and 5). Details on the development of these equations can be found at Curi. ${ }^{10}$

$$
\begin{aligned}
& \mathrm{R}_{\mathrm{H}_{2} \mathrm{O}}=\frac{\mathrm{i}}{2 \mathrm{~F}} \\
& \mathrm{R}_{\mathrm{CO}_{2}}=\frac{\mathrm{i}}{2 \mathrm{~F}}
\end{aligned}
$$

where $\mathrm{i}$ is the current drained by a charge coupled to the FC unit and $\mathrm{F}$ is the Faraday constant.

Regarding those problems, new materials should be researched and applied to replace Ni-YSZ-based anodes, focusing mainly on compounds that are flexible to the type of fuel used, and those more resistant to sulfur impurities, and also suitable for operation in low temperatures and long-term operation. The different SOFC anodes found in the literature are presented.

\section{Perovskite anodes}

The crystalline structure of a perovskite has the composition $\mathrm{ABX}_{3}$, where $\mathrm{A}$ and $\mathrm{B}$ are cations with different oxidation numbers and $\mathrm{X}$ is an anion. ${ }^{11} \mathrm{~B}$ cation occupies the cell unit center, while $\mathrm{A}$ cation and $\mathrm{X}$ anion occupy the vertices and edges of the unit cell, respectively. ${ }^{12,13}$ A typical perovskite is exemplified with the structure of $\mathrm{SrTiO}_{3}$ in Figure 5. Due to steric impediments from combinations of different ions, with different ionic radius, perovskite structures can present different degrees of distortions that even lead to different crystalline systems.

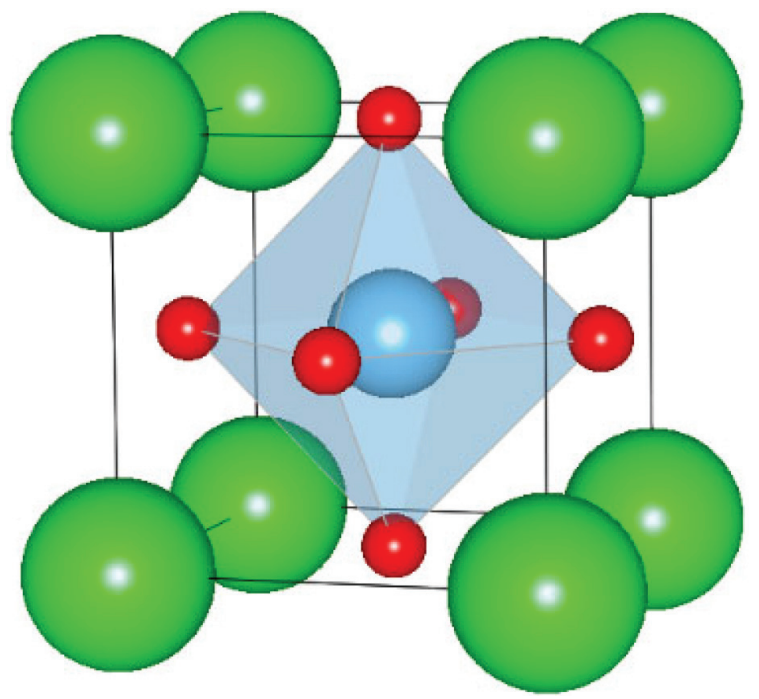

Figure 5. Crystalline structure of strontium titanate ( $\left.\mathrm{SrTiO}_{3}\right)$, Sr atoms are represented by green spheres, $O$ atoms in red and Ti in blue. Adapted from ref. 14

Vashook et al. ${ }^{15}$ synthesized a series of perovskite-type compounds $\mathrm{La}_{1-\mathrm{a}} \mathrm{Ca}_{\mathrm{a}} \mathrm{Cr}_{0.2} \mathrm{Ti}_{0.8} \mathrm{O}_{3-\delta}$ by the solid-state reaction technique (calcination temperature of $1350{ }^{\circ} \mathrm{C}$ ). The increase in the concentration of $\mathrm{Ca}$ decreases the thermal stability of the oxides related to the dissociation of oxygen. The maximum conductivity observed was $50 \mathrm{~S} \mathrm{~cm}^{-1}$ for a composition of $\mathrm{a}=0.95$ of dopant. This $\mathrm{Ca}$ composition corresponds to a $\mathrm{Cr}^{3+} / \mathrm{Cr}^{4+}=1$ ratio, oxygen stoichiometry $(3-\delta)=3$ and the oxidation states of $\mathrm{La}, \mathrm{Ca}$ and $\mathrm{Ti}$ ions of $3+, 2+$ and $4+$, respectively. In reducing atmosphere, the maximum conductivity is observed with a concentration of $\mathrm{a}=0.6$ of dopant, corresponding to the ratio of $\mathrm{Ti}^{3+} / \mathrm{Ti}^{4+}=1$, oxygen stoichiometry $(3-\delta)=2.92$ and the oxidation states of $\mathrm{La}, \mathrm{Ca}$ and $\mathrm{Ti}$ of $3+, 2+$ and $3+$, respectively. The change in conductivity of $\mathrm{La}_{1-\mathrm{a}} \mathrm{Ca}_{\mathrm{a}} \mathrm{Cr}_{0.2} \mathrm{Ti}_{0.8} \mathrm{O}_{3-\delta}$ from n-type to $\mathrm{p}$-type occurs with an increase in $\mathrm{Ca}$ content from $\mathrm{a}=0.7$ to $\mathrm{a}=0.9$. In addition, a change in the type of conductivity with a $=0.8$ was observed in extremely reducing atmospheres $\mathrm{p}_{\mathrm{O} 2}<10^{-10}$, where the conductivity is n-type (slope of the $\log (\sigma)$ versus $\log \left(\mathrm{p}_{\mathrm{O} 2}\right)$ is negative), while in oxidizing atmospheres $\mathrm{La}_{0.2} \mathrm{Ca}_{0.8} \mathrm{Cr}_{0.2} \mathrm{Ti}_{0.8} \mathrm{O}_{3-\delta}$ becomes a p-type semiconductor.

In Vashook et al. ${ }^{16}$ work, two series of perovskite $\mathrm{La}_{(1-\mathrm{x})} \mathrm{Ca}_{\mathrm{x}} \mathrm{TiO}_{3}$ $(\mathrm{x}=0.2-1)$ and $\mathrm{La}_{2(1-\mathrm{x}) / 3} \mathrm{Ca}_{\mathrm{x}} \mathrm{TiO}_{3}(\mathrm{x}=0.2-1)$ compounds were synthesized by the solid-state reaction technique (calcination temperature of $1350{ }^{\circ} \mathrm{C}$ ). Perovskite $\mathrm{La}_{0.4} \mathrm{Ca}_{0.4} \mathrm{TiO}_{3}$ revealed a tetragonal structure between $470 \mathrm{~K}$ and $1070 \mathrm{~K}$, and cubic at $1170 \mathrm{~K}$. The structure of the perovskite $\mathrm{La}_{2(1-x) / 3} \mathrm{Ca}_{\mathrm{x}} \mathrm{TiO}_{3}$ is stabilized with small amounts of $\mathrm{Ca}$. Point defects are considered for $\mathrm{La}_{(1-x)} \mathrm{Ca}_{\mathrm{x}} \mathrm{TiO}_{3-\delta}$ and $\mathrm{La}_{2(1-x) / 3} \mathrm{Ca}_{\mathrm{x}} \mathrm{TiO}_{3}$. The $\mathrm{n}$-type conduction can be explained by the creation of defects, associated with the reduction of $\mathrm{Ti}^{4+}$ to $\mathrm{Ti}^{3+}$ by the removal of oxygen (Equation 6):

$$
2 T i_{T i}^{x}+O_{O}^{x} \leftrightarrow 2 T i_{T i}^{\prime}+V_{\ddot{O}}+0.5 O_{2}
$$


Huang et al. (2006a) $)^{17}$ showed that each oxygen vacancy reduces 2 moles of $\mathrm{Mo}^{6+}$ to $\mathrm{Mo}^{5+}$, providing good electronic conductivity to $\mathrm{Sr}_{2} \mathrm{MnMoO}_{6-\delta}$ and $\mathrm{Sr}_{2} \mathrm{MgMoO}_{6-\delta}$ anodes. In the same work, it was found that the electronic conductivity decreases with the increase in the partial pressure of $\mathrm{O}_{2}$, but the conductivity of the $\mathrm{Sr}_{2} \mathrm{MnMoO}_{6-\delta}$ was more sensitive to pressure variation.

In Lepe et al. ${ }^{18}$ work, oxides with the general formula $\mathrm{Ln}_{2 / 3-\mathrm{x}} \mathrm{TiO}_{3-3 \mathrm{x} / 2}(\mathrm{Ln}=\mathrm{La}, \mathrm{Pr}$ and $\mathrm{Nd} ; 0.07 \leq \mathrm{x}<0.13)$ were prepared by a new synthesis route, adding $\mathrm{Ln}_{2 / 3-\mathrm{x}} \mathrm{Li}_{3 \mathrm{x}} \mathrm{TiO}_{3}$ precursors, prepared by two methods: solid-state reaction and sol-gel (modification of the Pechini process) ${ }^{19}$ followed by dehydration and calcination steps. Results from EIS showed that the resistance in the grain boundaries three times greater than that of the bulk for the lanthanum and praseodymium titanates. Comparing the two titanates, it was concluded that the resistance in the grain boundary region with $\mathrm{La}$ is smaller than that with Pr. This result can be attributed to small structural differences since the diffractogram of the compound with Pr shows peaks attributed to the tetragonal phase. The type of imperfections depends on the way the crystal was formed. Defects modify the electrical behavior of the material. Results presented proved that the conductivity in the bulk of the compound with La is greater than that with Pr.

Pudmich et al..$^{20}$ investigated materials with perovskite-type structures based on lanthanum chromates and strontium titanates as possible materials for SOFC anodes. Table 1 shows the studied materials. It was found that the higher the concentration of $\mathrm{Ti}$, the greater the electronic conductivity of the material while the increase in the concentration of $\mathrm{Cr}$ reduces the electronic conductivity of the same compound. In samples rich in $\mathrm{Cr}$, the electronic conductivity in air was higher than in the presence of $\mathrm{H}_{2}$. Thus, as a p-type conductor (excess of electron holes), conductivity is decreased in reducing atmospheres due to the reduction in electron holes in combination with increased $\mathrm{O}_{2}$ vacancy concentration. In the case of Ti-rich samples, conduction is n-type (excess of electrons) and charge carriers (electrons) are formed during the reaction. EIS measurements and analysis showed a certain activity of the $\mathrm{La}_{0.7} \mathrm{Sr}_{0.3} \mathrm{Cr}_{0.8} \mathrm{Ti}_{0.2} \mathrm{O}_{3}$ electrode on hydrogen oxidation, but the performance remained low when compared to the Ni-YSZ composite.

Chen and $\mathrm{Liu}^{21}$ evaluated the conductivity of $\mathrm{La}_{0.9} \mathrm{Sr}_{0.1} \mathrm{Ga}_{0.8} \mathrm{M}_{0.2} \mathrm{O}_{3}$ (LSGM) with $\mathrm{M}=\mathrm{Co}, \mathrm{Mn}, \mathrm{Cr}$, Fe or V. Among the transition metals studied, the samples doped with $\mathrm{Mn}$ and Co showed conductivity larger than the other samples. $\mathrm{La}_{0.9} \mathrm{Sr}_{0.1} \mathrm{Ga}_{0.8} \mathrm{Mn}_{0.2} \mathrm{O}_{3}$ presented the highest conductivity in the bulk. $\mathrm{La}_{0.9} \mathrm{Sr}_{0.1} \mathrm{Ga}_{0.8} \mathrm{Co}_{0.2} \mathrm{O}_{3}$ disintegrated under $\mathrm{H}_{2}$-reducing conditions and cannot therefore be used with anodic material. Among the different dopants for $\mathrm{LaGaO}_{3}, \mathrm{Co}$ resulted in the highest conductivity in air, while $\mathrm{Mn}$ provided the highest conductivity in a reducing atmosphere. Electrochemical measurements showed that $\mathrm{La}_{0.9} \mathrm{Sr}_{0.1} \mathrm{Ga}_{0.8} \mathrm{Mn}_{0.2} \mathrm{O}_{3}$ is a MIEC material with significant ionic conductivity, ionic and electronic resistance at $780{ }^{\circ} \mathrm{C}$ of $2.47 \Omega$ and $9.47 \Omega$, respectively, while $\mathrm{La}_{0.9} \mathrm{Sr}_{0.1} \mathrm{Ga}_{0.8} \mathrm{Co}_{0.2} \mathrm{O}_{3}$ presented high electronic conductivity (ion transfer number less than 1), ionic and electronic resistance at $780{ }^{\circ} \mathrm{C}$ of $33.56 \Omega$ and $2.43 \Omega$, respectively.

In Chen and $\mathrm{Liu}^{21}$ work, oxides of transition metals were doped with $\mathrm{LaGaO}_{3}$ in order to increase electronic conductivity while maintaining ionic conductivity, LSGM can be used as MIEC for SOFC and its use has two advantages: first, they are chemically and physically compatible with LSGM electrolytes, minimizing interfacial reactions due to diffusion or chemical reaction; second, their coefficients of thermal expansion are similar to that of the electrolyte, minimizing stress at the interface during the thermal cycle and, thus, improving the adhesion between the electrode and the electrolyte. However, measures of thermal expansion coefficients were not presented in that work.

$\mathrm{La}_{\mathrm{x}} \mathrm{Sr}_{1-\mathrm{x}} \mathrm{CrO}_{3}$ (LSC) has good stability in an anodic environment, however, $\mathrm{La}_{\mathrm{x}} \mathrm{Sr}_{1-\mathrm{x}} \mathrm{MnO}_{3}$ (LSM) has high electronic conductivity but is not stable in reducing atmospheres. For this reason, metal oxides with $\mathrm{La}_{0.75} \mathrm{Sr}_{0.25} \mathrm{Cr}_{1-\mathrm{x}} \mathrm{Mn}_{\mathrm{x}} \mathrm{O}_{3}$ (LSCM) composition ( $\mathrm{x}=0.4$, $0.5,0.6)$ were synthesized and examined as anode material for SOFC. ${ }^{22} \mathrm{La}_{0.75} \mathrm{Sr}_{0.25} \mathrm{Cr}_{0.6} \mathrm{Mn}_{0.4} \mathrm{O}_{3}, \mathrm{La}_{0.75} \mathrm{Sr}_{0.25} \mathrm{Cr}_{0.5} \mathrm{Mn}_{0.5} \mathrm{O}_{3}$ and $\mathrm{La}_{0.75} \mathrm{Sr}_{0.25} \mathrm{Cr}_{0.4} \mathrm{Mn}_{0.6} \mathrm{O}_{3}$ powders were synthesized by the glycine combustion. It was found that the conductivity of the anode increases with the partial pressure of oxygen and decreases with the $\mathrm{Cr}$ content. The densified samples show no differences in morphology. However, the crystalline structure changed from hexagonal, in air, to orthorhombic, in a reducing environment. In that same work, the LSCM tolerance to $\mathrm{H}_{2} \mathrm{~S}$ was measured, introducing $10 \% \mathrm{H}_{2} \mathrm{~S}$ into the hydrogen stream and the results showed that under open-circuit conditions the reaction products ( $\mathrm{MnS}$ and $\mathrm{MnOS}$ ) are conductive, which can reduce the resistance and improve the supply of electric current. This phenomenon can be explained because SOFC obtained a small increase in its performance after being fed with fuel contaminated with sulfur. However, under potentiostatic conditions (control of the voltage difference between the working electrode and the reference electrode with current injection), the intermediate species and the products formed can accelerate anode poisoning, especially in the $3 \mathrm{~PB}$.

The physical properties and the level of mixed conduction presented by the compounds $\mathrm{Sr}_{0.97} \mathrm{Ti}_{0.6} \mathrm{Fe}_{0.4} \mathrm{O}_{3-\delta}$ (STFO) and $\mathrm{La}_{0.4} \mathrm{Sr}_{0.5} \mathrm{Ti}_{0.6} \mathrm{Fe}_{0.4} \mathrm{O}_{3-\delta}$ (LSTFO) were studied by Fagg et al. ${ }^{23}$ The powders were prepared by the solid-state reaction from $\mathrm{TiO}_{2}, \mathrm{Fe}_{2} \mathrm{O}_{3}$, $\mathrm{La}_{2} \mathrm{O}_{3}$ and $\mathrm{SrCO}_{3}$. STFO was sintered at $1400{ }^{\circ} \mathrm{C}$ and LSTFO at $1600{ }^{\circ} \mathrm{C}$. The use of the highest temperature for LSTFO is necessary to achieve phase purity and good densification. Deficiency at the A site (La and $\mathrm{Sr}$ in LSTFO, and Sr in STFO) was introduced in both compositions, with a unit ratio of $\mathrm{A} /(\mathrm{Ti}+\mathrm{Fe})$, in order to improve the stability of these materials. The lowest total conductivity for LSTFO was observed, which can be attributed to the low concentration of electron holes under oxidation conditions. The main factor that affects the level of ionic conduction is the high activation energy of

Table 1. Name, chemical composition, and crystallographic properties of the powders after sintering $1400^{\circ} \mathrm{C}$. Adapted from ref. 20

\begin{tabular}{ccccc}
\hline Acronym & Composition & Crystal system & Lattice constant $(\AA)$ & Secondary phase \\
\hline LCCT-7382 & $\mathrm{La}_{0.7} \mathrm{Ca}_{0.3} \mathrm{Cr}_{0.8} \mathrm{Ti}_{0.2} \mathrm{O}_{3}$ & Orthorhombic & $\mathrm{a}=5.4663 \mathrm{~b}=5.4755 \mathrm{c}=7.7309$ & \\
LCCT-7355 & $\mathrm{La}_{0.7} \mathrm{Ca}_{0.3} \mathrm{Cr}_{0.5} \mathrm{Ti}_{0.5} \mathrm{O}_{3}$ & Orthorhombic & $\mathrm{a}=5.4736 \mathrm{~b}=5.4837 \mathrm{c}=7.7459$ & $\mathrm{La}_{4} \mathrm{Ca}_{2} \mathrm{Ti}_{5} \mathrm{O}_{18}$ \\
LCCT-7328 & $\mathrm{La}_{0.7} \mathrm{Ca}_{0.3} \mathrm{Cr}_{0.2} \mathrm{Ti}_{0.8} \mathrm{O}_{3}$ & Not determined & & $\mathrm{La}_{4} \mathrm{CaTi}_{5} \mathrm{O}_{17}$ \\
LCT-73X & $\mathrm{La}_{0.7} \mathrm{Ca}_{0.3} \mathrm{TiO}_{3}$ & Not determined & & $\mathrm{Ca}_{2} \mathrm{La}_{0.67}\left(\mathrm{VO}_{4}\right)_{2}$ \\
LCCF-7382 & $\mathrm{La}_{0.7} \mathrm{Ca}_{0.3} \mathrm{Cr}_{0.8} \mathrm{Fe}_{0.2} \mathrm{O}_{3}$ & Orthorhombic & $\mathrm{a}=5.4587 \mathrm{~b}=5.4776 \mathrm{c}=7.8287$ & $\mathrm{a}=5.4693 \mathrm{~b}=5.4817 \mathrm{c}=7.7167$ \\
LCCV-7382 & $\mathrm{La}_{0.7} \mathrm{Ca}_{0.3} \mathrm{Cr}_{0.8} \mathrm{~V}_{0.2} \mathrm{O}_{3}$ & Orthorhombic & $\mathrm{a}=5.5047 \mathrm{c}=13.3504$ & \\
LSCT-7382 & $\mathrm{La}_{0.7} \mathrm{Sr}_{0.3} \mathrm{Cr}_{0.8} \mathrm{Ti}_{0.2} \mathrm{O}_{3}$ & Hexagonal & &
\end{tabular}


LSTFO, which may be due to the significant formation of vacancy mobilities, in addition, the increase in temperature should increase the concentration of vacancies present. It should also be considered that LSTFO exhibits an orthorhombic structure while STFO exhibits cubic structure. These two structures do not exhibit the same enthalpy for ion migration and vacancy formation. However, the polymorphism change is not related to the high activation energy. Examples against this hypothesis are that compounds such as $\mathrm{La}_{0.9} \mathrm{Sr}_{0.1} \mathrm{Ga}_{0.8} \mathrm{Mg}_{0.2} \mathrm{O}_{3-\delta}$ with orthorhombic structure, still exhibit high levels of ionic conductivity with activation energy around $100 \mathrm{~kJ} \mathrm{~mol}^{-1}$. In that work, the ionic conductivity was separated from the total conductivity by using the Faradaic efficiency, based on EIS measurement data, presented in Kharton et al. ${ }^{24}$ The number of ions transfer ranged from 0.005 to 0.08 to $\mathrm{Sr}_{0.97} \mathrm{Ti}_{0.6} \mathrm{Fe}_{0.4} \mathrm{O}_{3-\delta}$, decreasing as the temperature decreases. The conductivity of the electron holes of the oxide was small, but exceeded the ionic conductivity, showing that the behavior of the p-type semiconductor was more pronounced. The activation energy for the electronic conductivity was $35 \mathrm{~kJ} \mathrm{~mol}^{-1}$ between 470 and $890 \mathrm{~K}$ (calculated by the Arrhenius model), being reduced to higher temperatures. Thermogravimetric analysis (TGA) in different atmospheres showed that at temperatures above $770 \mathrm{~K}$ the $\mathrm{Sr}_{0.97} \mathrm{Ti}_{0.6} \mathrm{Fe}_{0.4} \mathrm{O}_{3-\delta}$ perovskite phase is stable concerning the reaction with $\mathrm{CO}_{2}$. However, the exposure of STFO powders to lower temperatures can result in the decomposition of its surface associated with the formation of $\mathrm{SrCO}_{3}$.

Ruiz-Morales et al. ${ }^{25}$ studied the substitution of Ti in $\mathrm{La}_{4} \mathrm{Sr}_{8} \mathrm{Ti}_{12-\mathrm{x}} \mathrm{M}_{\mathrm{x}} \mathrm{O}_{38-\delta}$ with $\mathrm{M}=\mathrm{Mn}, \mathrm{Ga}$ or Sc controlling oxygen stoichiometry. The best composition for the lowest polarization resistance observed for the oxide was $\mathrm{M}=\mathrm{Ga}$ and $\mathrm{x}=0.5$ $\left(\mathrm{La}_{4} \mathrm{Sr}_{8} \mathrm{Ti}_{11.5} \mathrm{Ga}_{0.5} \mathrm{Mn}_{0.5} \mathrm{O}_{37.5}\right.$ ) (LSTMG) both in reducing conditions with $\mathrm{H}_{2}$ fuel $\left(2.3 \% \mathrm{v} / \mathrm{v}_{2} \mathrm{O}\right)$ as with $\mathrm{CH}_{4}\left(2.3 \% \mathrm{v} / \mathrm{v} \mathrm{H}_{2} \mathrm{O}\right)$, presenting a lower polarization resistance of 0.20 and $0.57 \Omega \mathrm{cm}^{2}$, respectively, which were less than for $\mathrm{x}=0$ (2.97 and $8.93 \Omega \mathrm{cm}^{2}$, respectively), $\mathrm{M}=\mathrm{Sc}$ and $\mathrm{x}=0.6\left(0.5\right.$ and $1.20 \Omega \mathrm{cm}^{2}$, respectively $)$ and $\mathrm{M}=\mathrm{Mn}$ and $\mathrm{x}=1$ (0.43 and $1.14 \Omega \mathrm{cm}^{2}$, respectively). $\mathrm{Mn}$ and $\mathrm{Ga}$ have lower coordination numbers (fewer neighboring atoms), especially $\mathrm{Mn}^{3+}$, and thus facilitate the migration of the oxygen ion. Thus, with the addition of Mn and Ga, MIEC is promoted by accelerating the electrocatalytic processes at the interfaces.

In the study by Vernoux et al., ${ }^{26} \mathrm{La}_{0.8} \mathrm{Sr}_{0.2} \mathrm{Cr}_{0.97} \mathrm{~V}_{0.03} \mathrm{O}_{3}$ anode (LSCV) in the conversion of methane exhibited low activity at 800 and $850{ }^{\circ} \mathrm{C}$, but no carbon deposition was detected after $30 \mathrm{~h}$ of operation. EIS measurements of the LSCV-YSZ composite showed that the high-frequency semicircle (HF) is probably related to the electrode/electrolyte microstructure interface, while the medium frequency semicircle (MF) may be associated with electrochemical reaction in $3 \mathrm{~PB}$.

In the article by Vernoux et al. $,{ }^{27} \mathrm{LSC}, \mathrm{LCR}$ and LSCM powders with a nominal composition of $\mathrm{La}_{0.8} \mathrm{Sr}_{0.2} \mathrm{CrO}_{3-\delta}, \mathrm{LaCr}_{0.95} \mathrm{Ru}_{0.05} \mathrm{O}_{3-\delta}$ and $\mathrm{La}_{0.8} \mathrm{Sr}_{0.2} \mathrm{Cr}_{0.8} \mathrm{Mn}_{0.2} \mathrm{O}_{3-\delta}$, respectively, were synthesized by spray pyrolysis (ultrasonic atomization technique) and the films were prepared by spray printing (deposition and printing from atomized powders). Results of catalytic activity prove that the insertion of $\mathrm{Ru}$ in the structure accelerates the methane reform. The thermal behavior of $\mathrm{La}_{0.8} \mathrm{Sr}_{0.2} \mathrm{CrO}_{3-\delta}$ (LSC) was assessed using dilatometry. At $500{ }^{\circ} \mathrm{C}$, a contraction was observed, probably due to the decomposition of $\mathrm{LaNO}_{3}$. LSC X-ray diffractometry (XRD) studies have shown the presence of $\mathrm{MCrO}_{4}(\mathrm{M}$ is $\mathrm{La}$ or $\mathrm{Sr}$ ), which is a product of the decomposition of chromium and lanthanum nitrates in the air. In the XRD of LSC powders prepared by spray pyrolysis (SP), the investigated phase of LSC was visible after SP at $800{ }^{\circ} \mathrm{C}$ for $8 \mathrm{~s}$. The presence of a secondary phase can be attributed to the presence of the monoclinic structure $\mathrm{SrO}_{4}$, or the solid solution, such as lanthanum or strontium chromates. Other results show that the secondary phase disappeared after $1100{ }^{\circ} \mathrm{C}$ for 4 hours.

TGA curves showed in mass loss between $750{ }^{\circ} \mathrm{C}$ and $780{ }^{\circ} \mathrm{C}$, in that same temperature range, there was a drop in the dilatometric curve. In this way, it can be said that the chromates of $\mathrm{La}$ and $\mathrm{Sr}$ were completely transformed into LSC between $750-780{ }^{\circ} \mathrm{C}$ to $1230{ }^{\circ} \mathrm{C}$. Chromatographic analyzes showed two peaks of $\mathrm{CO}$ and $\mathrm{CO}_{2}$ for the Ni-YSZ anode and only one peak of $\mathrm{O}_{2}$ for LSCM, this means that the carbon formed by the coke reaction is present on the Ni-YSZ surface. Results from EIS showed that Mn insertion improves the electrochemical activity of perovskites. LCR was not investigated via EIS due to its low electronic conductivity (no Sr content). ${ }^{27}$

Sfeir ${ }^{28}$ analyzed the stability of $\mathrm{LaCrO}_{3}$ when doped with $\mathrm{Mg}, \mathrm{Ca}$, $\mathrm{Sr}, \mathrm{Mn}, \mathrm{Fe}, \mathrm{Co}$ and $\mathrm{Ni}$ against various atmospheres (air, humidified hydrogen, $\mathrm{CO}$ and $\mathrm{CO}_{2}$ ). Experimental and thermodynamic data showed at the A-site, the substitution of $\mathrm{Sr}$ is more stable than that of $\mathrm{Ca}$ in reducing atmospheres since the solubility limit of $\mathrm{Ca}$ is low under partial pressure of $\mathrm{O}_{2}$ at $10^{-9}$ atm at $1600{ }^{\circ} \mathrm{C}$. $\mathrm{CO}$ and $\mathrm{CO}_{2}$ did not affect the stability of these perovskites, once there is no carbon formation and secondary phases were observed. $\mathrm{H}_{2} \mathrm{O}$ and $\mathrm{H}_{2}$ cause corrosion in these perovskites because the volatility of $\mathrm{Ca}, \mathrm{Sr}$ and $\mathrm{Cr}$ is pronounced due to the formation of hydroxyls. The secondary phases formed during the decomposition can react quickly with YSZ at $800{ }^{\circ} \mathrm{C}$, although the substituting compounds of the B-site $(\mathrm{Mg}, \mathrm{Mn}$, $\mathrm{Fe}, \mathrm{Co}$ and $\mathrm{Ni}$ ) have shown to be more thermodynamically unstable.

Ceramics with perovskite-type structures, such as $\mathrm{SrTiO}_{3}$, have a great possibility of improving and/or altering their physical and chemical properties and characteristics through doping processes aiming application as SOFC anodes. Doping cations introduce mixed valences and oxygen vacancies into the unit cell. However, when doping those structures, the stability of the material is altered, since the insertion of impurity ions causes distortions in the structural geometry of the crystal lattice, as they present ionic radii that differ from the original configuration. ${ }^{29-31}$ In the A-site, in order to accommodate an ion with an ionic radius greater than the ionic radius of $\mathrm{Sr}$ the $\mathrm{TiO}_{6}$ octahedron elongates slightly. Because of this, the Ti ion is no longer the center of symmetry of the unit cell. ${ }^{32}$ When ions with an ionic radius smaller than the ionic radius of $\mathrm{Sr}$ or with an ionic radius smaller than that of $\mathrm{Ti}$ are introduced at sites $\mathrm{A}$ and $\mathrm{B}$, respectively, the tolerance factor $(\mathrm{T})$ becomes smaller than 1 . In this case, the ion located at site A no longer contacts the 12 oxygen ions. Then the structure adjusts by performing rotations in the $\mathrm{TiO}_{6}$ octahedron, to maintain the regularity of the structure and the correct sharing of spaces between the ions, so that the ions coming from the $\mathrm{TiO}_{6}$ octahedron approach the smaller ion now located at A-site. ${ }^{33}$ This rotation in the structure has as the main consequence (besides the loss of symmetry), the change in the angle of the Ti-O-Ti connection from $180^{\circ}$ to approximately $165^{\circ}$. This effect also leads to a decrease in the coordination number of the A-site cation from 12 to a value between 8 and 10. Both effects alter the electrical characteristics of the material, as they will change the interatomic distances, leading to changes in the band diagrams and in the strength of the Ti-O-Ti bond. ${ }^{29}$

Perovskite structures such as $\mathrm{SrTiO}_{3}$ in their stoichiometric form $(\mathrm{Sr} / \mathrm{Ti}=1, \mathrm{O} / \mathrm{Sr}=3)$ have a bandgap of $3.2 \mathrm{eV}$ at $0 \mathrm{~K}$. They are considered a proper material for applications as an insulator. ${ }^{34,35}$ By convention, it is considered that all compounds with a bandgap above $2 \mathrm{eV}$ are insulator, and less than that, semiconductor (remembering that in metallic materials there is no bandgap due to an overlap of the conduction and valence bands). ${ }^{36}$ When there is no compensatory distortion in the $\mathrm{TiO}_{6}$ octahedron, the highest occupied molecular orbital (HOMO) that corresponds to the valence band is predominantly atomic ( $2 \mathrm{~s}$ and $2 \mathrm{p}$ oxygen orbitals). The conduction band, which corresponds to the lowest unoccupied molecular orbital 
(LUMO), is predominantly cationic and it comes from the unoccupied energy states of the Ti-d orbital. Such difference between the states of HOMO and LUMO is what characterizes $\mathrm{SrTiO}_{3}$ as a robust insulator (dielectric).

There are many studies on the doping process at B-site, mainly with the substitution by cations of $\mathrm{Fe}^{3+/ 2+}$ and $\mathrm{Al}^{3+}$. Synthesis of $\mathrm{B}$-sites doped $\mathrm{SrTiO}_{3}$ structures is widely applied in order to change the ionic and electronic transport properties of the material. Normally, cations with a valence greater than or equal to $3+$ are used and the structure is compensated by the formation of oxygen vacancies. Kharton et al. ${ }^{37}$ used iron ions to perform the doping process at site $\mathrm{B}$, and a decrease in the size of the crystalline cell due to the steric compensations was noted. The authors observed that the structure had an increase in ionic and electronic conductivities, showing that such doping is advantageous. The activation energy for ionic conductivity was independent of the dopant concentration and it has varied from 97 to $104 \mathrm{~kJ} \mathrm{~mol}^{-1}$. The TEC is feasible with that relative to the YSZ $\left(1.05 \times 10^{-5} \mathrm{~K}^{-1}\right):^{38}$ in a temperature range between 300 and $720 \mathrm{~K}$, they have found $1.2 \times 10^{-5} \mathrm{~K}^{-1}$ to the minor concentration of dopant and $2.1 \times 10^{-5} \mathrm{~K}^{-1}$ to $8 \% \mathrm{Fe}$. Kharton et al. ${ }^{37}$ were based on studies by Steinsvik et al. ${ }^{39}$ They have doped the titanate structure with iron concentrations that varied from 0 to $8 \%$ and concluded that the structures compensate for the charge imbalance with the formation of oxygen vacancies. When the doping concentration was greater than $6 \%$, a crystalline cell was formed, characterized as a superstructure with a lattice constant twice than the one from the simple perovskite. This phenomenon was associated due to structural reorganization from the accumulation of oxygen vacancies. The authors have also concluded that the high level of mixed ionic/electronic conductivity makes this material able to use as an electrode of SOFC.

Doping processes with $\mathrm{Fe}$ cations are the most representative model for doping with acceptors in $\mathrm{SrTiO}_{3}$ electroceramics with wide bandgap. The mixture of valence $\mathrm{Fe}^{3+}$ and $\mathrm{Fe}^{2+}$ creates a series of imbalances with the charges. This will be compensated by the creation of oxygen vacancies whose concentration varies according to the partial pressure regime of oxygen. Kubacki et al..$^{40}$ studied the influence of $\mathrm{Fe}$ insertion in the $\mathrm{SrTiO}_{3}$ band structure and concluded that $\mathrm{Fe}^{+3}$ and $\mathrm{Fe}^{+2}$ affect energy bands differently. The first results in a peak-shaped energy state just above the top of the valence band, while the second results in a wider-shaped state in the prohibited band just below $0.5 \mathrm{eV}$. No state in the Fermi energy region has been created, although there is a hybridization between the Ti and $\mathrm{Fe}$ and Ti orbitals and oxygen vacancies, these generate new electronic states proportional to the Fe concentration. Baker et al.,${ }^{41}$ studying the influence of $\mathrm{Fe}$ ions on the position of Fermi energy, concluded that when the $\mathrm{Fe}$ atom is at the $\mathrm{Ti}\left(\mathrm{Fe}_{\mathrm{Ti}}\right)$ site, it assumes valences that can vary from $1+$ to 2 - in its new energetic state in the middle of the bandgap, this is in the position of $1.7 \mathrm{eV}$ above the top of the valence band. $\mathrm{Li}$ et al. ${ }^{42}$ aiming at the application of $\mathrm{SrTiO}_{3}$ structures in the anode compartment of a SOFC, inserted iron cations at B-site and concluded that the conductivity increased proportionally with the increase in the concentration of impurity and the increase in temperature up to the maximum by around $800{ }^{\circ} \mathrm{C}$ then started to decrease. Such conductivity profile in relation to the increase in temperature indicates a predominance of concentration of holes as mainly a source of generation of electrical conductivity.

The study of the influence of $\mathrm{Al}^{3+}$ ions has also been shown to be representative in the synthesis of extrinsic p-type semiconductors of $\mathrm{SrTiO}_{3}$ electroceramics. Morin and Oliver ${ }^{43}$ studied the formation of energy levels in the forbidden band with the introduction of aluminum atoms. An energy level of holes (also called an electron trap) was identified below the beginning of the conduction band with $0.3 \mathrm{eV}$. This band showed a higher density of holes at $0.09 \mathrm{eV}$ below conduction.
Zhao et al..$^{44}$ found that the incorporation of $\mathrm{Al}^{3+}$ reduces the possibility of recombination between $\mathrm{Ti}^{3+}$ and $\mathrm{Ti}^{4+}$, however, in contrast, it decreases Fermi energy by approximately $0.5 \mathrm{eV}$. The influence of aluminum ions in the structure will depend on their respective locations in relation to oxygen vacancies: if the oxygen vacancy is surrounded by less than two $\mathrm{Al}^{3+}$ ions, adjacent $\mathrm{Ti}^{4+}$ ions are formed, generating a complex $\left\{\mathrm{Ti}^{4+} / \mathrm{V}_{\mathrm{O}}\right\}$. However, due to Fermi's low energy, these states are not permanently occupied by electrons, and can, therefore, promote electron-hole recombination. Bowes et al. ${ }^{45}$ when publishing a collection of physicochemical and band information of various types of impurities in $\mathrm{SrTiO}_{3}$ structures, showed that when inserting $\mathrm{Al}^{3+}$ ions into the Ti site, Fermi energy is located in values between 0.01 and $0.15 \mathrm{eV}$, depending on the compensation mechanism of the structure to recover the load balance.

There are also promising studies on doping with niobium $\left(\mathrm{Nb}^{5+}\right)$ : Smith et al. ${ }^{46}$ synthesized $\mathrm{SrTiO}_{3}$ structures doped with $\mathrm{Ta}^{5+}$ at concentrations of $1 \%, 5 \%$ and $10 \%$. The authors concluded that the lattice constant increases proportionally with the increase in the concentration of dopant and this happens due to the fact that, instead of the replacement of $\mathrm{Ti}^{4+}$ by $\mathrm{Ta}^{5+}$, there is an electronic compensation that occurs by converting $\mathrm{Ti}^{4+}$ to $\mathrm{Ti}^{3+}$ and the latter presents greater ionic radius. Such a mechanism is favored by the presence of reducing agents in the atmosphere, leading to the simultaneous formation of oxygen vacancies. The authors also studied the compatibility between the synthesized structures and YSZ and observed that there was no additional phase or chemical and/or physical segregation on the interface.

Zhang et al. ${ }^{47}$ in their results, showed that with the insertion of $\mathrm{Nb}$, the Fermi level moves considerably towards the conduction band, due to the accumulation of electrons; that is generated with the incorporation of defects. The valence band will consist of the states $\mathrm{O} 2 \mathrm{p}$ and the conduction band will be formed by the states Ti $3 \mathrm{~d}$ and $\mathrm{Ti} 4 \mathrm{~d}$. Blennow et $a l .{ }^{48}$ studied the transport of defects and electrons in $\mathrm{SrTiO}_{3}$ structures doped with $\mathrm{Nb}$, the authors showed that the concentration of $\mathrm{Nb}$ directly affects the density of states close to the Fermi energy, changing it to energies with values closer to the conduction band. The compensation mechanisms consisted in the presence of electronic exchange $\left(\mathrm{Ti}^{4+}\right.$ atoms are reduced to $\left.\mathrm{Ti}^{3+}\right)$, with no vacancy formation. The $\mathrm{Nb}$ atoms remain with fixed oxidation and the partial pressure of oxygen has no direct influence on conductivity. The authors also found evidence that the presence of niobium intensifies the overlapping of the atomic Ti orbitals, intensifying the electrical conductivity of the structure. Ozdogan et al. ${ }^{49}$ showed that, in addition to the energy levels mentioned above, niobium influences the conduction band more through the overlapping of the Ti $3 \mathrm{~d}$ and $\mathrm{Nb} 4 \mathrm{~d}$ energy states than in the valence band. Blennow et al. ${ }^{48}$ applied structures of $\mathrm{SrTiO}_{3}$ doped with $\mathrm{Nb}$ at the $\mathrm{B}$-site in SOFC anodes, and they have not obtained catalytic activity for the redox reactions. Smith et al. ${ }^{46}$ studied the effect of doping with tantalum on the operation as an anode of a SOFC and they obtained good chemical compatibility with the electrolyte of YSZ during the redox cycles.

Regarding the doping of A-site, there are many studies about the insertion of lanthanum as an electron donor. Biswas et al..$^{50}$ studying this structure with $10 \%$ of dopant have found a Fermi energy of $0.2 \mathrm{eV}$ from the base of the conduction band. The authors have stated that negative charge carriers were inserted in the structure satisfactorily by the incorporation of La ions and that the conduction band consists mainly of the $3 \mathrm{~d}$ and $5 \mathrm{~d}$ orbitals (coming from $\mathrm{Ti}$ ) since the contributions of the $\mathrm{s}$ and $\mathrm{p}$ orbitals are minimal. Electrical conduction takes place mainly in hybrid Ti-O orbitals that the authors call channels. Hashimoto et al. ${ }^{51}$ have studied how the conductivity of the material behaved in face of changes in temperature and atmosphere and they have concluded that in a reducing atmosphere 
the structure has undergone a significant hysteresis depending on the temperature and, above a concentration of $3 \% \mathrm{La}$, the material has a conductivity that is slightly dependent on temperature or partial pressure of oxygen. They also concluded that an oxidizing atmosphere promotes the excess of charges, which causes compensation with the formation of a secondary $\mathrm{SrO}$ phase, leading to a decrease in electronic conductivity. Marina et al..$^{52}$ concluded that $\mathrm{SrTiO}_{3}$ doped with La presents a higher total conductivity when analyzed in a reducing atmosphere. However, Li et al. ${ }^{53}$ reported that sintering in a reducing atmosphere compensates the A-site deficiencies by charge reorganization, generating oxygen vacancies and increasing the valence of titanium atoms. Therefore, once deficiencies at A-site increase, ionic conductivity also increases (since it is proportional to the concentration of vacancies) and electronic conductivity decreases (because there is less possibility of exchange between the $3+$ and $4+$ valences of titanium).

Another ion that has shown potential in doping A-site of $\mathrm{SrTiO}_{3}$ structures is yttrium. The band structure of such material was studied by Drozdz et al.,$^{54}$ the authors show that, when introducing such a dopant, there is a shift in the Fermi level from the bandgap to the conduction band. An increase in the concentration of $\mathrm{Y}$ intensifies this shift towards higher energy in the same band and decreases the curvature of the band shape near the base of the conductive band.

Shan and $\mathrm{Yi}^{55}$ evaluated the electronic conductivity of $\mathrm{SrTiO}_{3}$ structures co-doped with Y and In, as a function of temperature, finding maximum electronic conductivity in the temperature range between 400 and $500{ }^{\circ} \mathrm{C}$. Chen et al..$^{56}$ observed that these structures exhibit metallic conduction behavior from a temperature of approximately $300{ }^{\circ} \mathrm{C}$, with maximum conductivity also at this temperature, but did not evaluate the behavior at temperatures above $700{ }^{\circ} \mathrm{C}$. They also showed that the concentration of $\mathrm{Ti}^{3+}$ ions increases with the dopant increase up to the value of $8 \%$, then remains constant due to the formation of the secondary phase of pyrochlore $\mathrm{Y}_{2} \mathrm{Ti}_{2} \mathrm{O}_{7}$. Although these studies correlate the electronic conductivity of the material in the face of the effect of temperature and dopant concentration, there is little information about the influence of processing parameters (as in the calcination and sintering steps) on the electrical properties of the material. Gao et al. ${ }^{57}$ when synthesizing strontium titanate structures doped with yttrium also showed an increase in the concentration of oxygen vacancies that arise to compensate for the decrease in the concentration of $\mathrm{Ti}^{3+}$. As this is responsible for electronic conduction, as seen in the state density, it will result in a decrease in electrons in the allowed states of the conduction band. Since compensation is via vacancies, they help to increase ionic conductivity.

Hui and Petric ${ }^{58}$ studied the redox behavior of $\mathrm{Sr}_{0.88} \mathrm{Y}_{0.08} \mathrm{TiO}_{3}$ and noticed that the variation in electrical conductivity in both the reduction and oxidation processes exhibit parabolic dependence over time. However, the reduction rate is slower than the oxidation rate (Equation 7).

$$
O_{O}^{x} \leftrightarrow 2 e^{-}+V_{\ddot{O}}+\frac{1}{2} O_{2(g)}
$$

For a material to be a potential candidate as FC anode, the variation in electrical conductivity must be rapid in both oxidation and reduction. The reduction of $\mathrm{Sr}_{0.88} \mathrm{Y}_{0.08} \mathrm{TiO}_{3-\delta}$ implies the release of oxygen from the network and results in the electrons and vacancies; the reverse process occurs during oxidation. The redox process performance can be described by the following Equation $8 .{ }^{58}$

$$
\eta=\frac{\Delta \mathrm{W}_{\mathrm{t}}-\Delta \mathrm{W}_{0}}{\Delta \mathrm{W}_{\infty}-\Delta \mathrm{W}_{0}}
$$

where $\Delta \mathrm{W}$ is the weight loss or oxygen variation from stoichiometry in relation to the theoretical composition, $\mathrm{t}, 0$ and $\infty$ correspond to arbitrary, initial and final times, respectively. In terms of conductivity, this performance is given by Equation 9: ${ }^{58}$

$$
\eta=\frac{\sigma_{t}-\sigma_{0}}{\sigma_{\infty}-\sigma_{0}}
$$

Results showed the conductivity of $\mathrm{Sr}_{0.88} \mathrm{Y}_{0.08} \mathrm{TiO}_{3-\delta}$ changes quickly at the beginning and reached a plateau, which is a typical behavior of diffusion-controlled processes ${ }^{58}$ it is shown when there was a rapid pressure change on the surface at $800{ }^{\circ} \mathrm{C}$ for both processes (oxidation and reduction). Changes in composition must be due to mass transport via diffusion of the gas-solid interface for reduction or vice-versa in oxidation. In the reduction process, the $\mathrm{Sr}_{0.88} \mathrm{Y}_{0.08} \mathrm{TiO}_{3-\delta}$ nucleus was reduced by the diffusion of oxygen vacancies and at the reduced/oxidized oxide interface whose area decreased with time. The distance from this interface to the surface increased over time, as do the reduction rates or the conductivity decreases over time. For most oxides, diffusion of oxygen at the grain boundary is faster than diffusion in the bulk of grains. As a result, when partial pressure of oxygen is varied, a change in stoichiometry occurs at the grain boundary. They can perform as a reduction path or as a blocking barrier during oxidation.

The performance of $\mathrm{Sr}_{0.85} \mathrm{Y}_{0.10} \mathrm{Ti}_{0.95} \mathrm{Ga}_{0.05} \mathrm{O}_{3-\delta}$ and $\mathrm{Sr}_{0.85} \mathrm{Y}_{0.10} \mathrm{Ti}_{0.95} \mathrm{Co}_{0.05} \mathrm{O}_{3-\delta}$ compounds, using $\mathrm{La}_{0.8} \mathrm{Sr}_{0.2} \mathrm{Ga}_{0.8} \mathrm{Mg}_{0.3} \mathrm{O}_{2.8}$ (LSGM) and YSZ electrolyte, was studied by Hui and Petric..$^{58}$ Both compositions resulted in low power densities (maximum value of $58 \mathrm{~mW} \mathrm{~cm}^{-2}$ at $900{ }^{\circ} \mathrm{C}$ and partial pressure of $\mathrm{O}_{2} 10^{-20} \mathrm{~atm}$ ) that can be attributed to the high contact resistance between the anode and electrolyte. The ohmic resistance can be reduced by decreasing the thickness of the electrolyte and the electrode with the use of tape manufacturing and laminating techniques, such as tape casting and screen printing of the electrodes.

Hui and Petric ${ }^{58}$ also studied the effect of porosity on the conductivity of $\mathrm{Sr}_{0.88} \mathrm{Y}_{0.08} \mathrm{TiO}_{3-\delta}$ and $\mathrm{Sr}_{0.85} \mathrm{Y}_{0.10} \mathrm{Ti}_{0.95} \mathrm{M}_{0.05} \mathrm{O}_{3-\delta}$ with the addition of $20 \%(\mathrm{w} / \mathrm{w})$ of carbon. There was a decrease in conductivity in porous samples compared to dense samples. They proposed a mathematical model that agrees with the results obtained experimentally. This model is a relationship between the conductivity of the dense and porous material $\left(\sigma / \sigma^{0}\right)$ as a function of the porosity of ceramic materials, and considers that the spherical pores are evenly distributed in the dense materials, as it is shown by Equation 10 .

$$
\sigma / \sigma^{0}=(1-\varepsilon) /(1+0.5 \varepsilon)
$$

where $\varepsilon=\left(1-\rho / \rho_{0}\right)$ is the porosity, $\rho$ and $\rho_{0}$ are the real and theoretical densities, respectively.

Hui and Petric ${ }^{58}$ measured the electrical conductivity of $\mathrm{SrTiO}_{3}$ doped with yttria with different transition metals added as load accepting dopants $(\mathrm{M}=\mathrm{V}, \mathrm{Mn}, \mathrm{Fe}, \mathrm{Co}, \mathrm{Ni}, \mathrm{Cu}, \mathrm{Zn}, \mathrm{Mo}, \mathrm{Mg}, \mathrm{Zr}$, $\mathrm{Al}$ or $\mathrm{Ga}$ ) in the temperature range of $600-900{ }^{\circ} \mathrm{C}$ in a reducing atmosphere. The substitution of 5\% (mol) of Ti by dopants decreases the conductivity of $\mathrm{Sr}_{1-1.5 \mathrm{x}} \mathrm{Y}_{\mathrm{x}} \mathrm{TiO}_{3-\delta}$, that is, the degree of conductivity depends on the type of dopant. The catalytic activity of perovskites depends mainly on the ions of the B site, that is, on a metal after its reduction, and its effectiveness in decreasing order can be described as $\mathrm{Co}>\mathrm{Mn}>\mathrm{Ni}>\mathrm{Fe}>\mathrm{Cr}$ and $\mathrm{Sr}$ is the ion from the corresponding A-site that has the best catalytic activity at $800{ }^{\circ} \mathrm{C}$ in the partial oxygen pressure range between $10^{-20}$ and 0.21 atm. Results of the effects of charge acceptor dopants on the conductivity at $800{ }^{\circ} \mathrm{C}$ as a function of the partial pressure of oxygen in the compounds $\mathrm{Sr}_{0.85} \mathrm{Y}_{0.10} \mathrm{Ti}_{0.95} \mathrm{M}_{0.05} \mathrm{O}_{3-\delta}$ and $\mathrm{Sr}_{0.88} \mathrm{Y}_{0.08} \mathrm{Ti}_{0.95} \mathrm{M}_{0.05} \mathrm{O}_{3-\delta}$ showed that in 
all cases conductivity decreased (except for Co). This is because the conductivity of perovskites depends mainly on the B-O bond strength, the electrons induced by the reduction consequently of the ease of breaking the B-O bond. B, in this case, can be the ions of the transition metals of $\mathrm{Co}, \mathrm{Mn}, \mathrm{Ni}, \mathrm{Fe}$ or $\mathrm{Cr}$. Thus, the enthalpy of formation $\left(\Delta \mathrm{H}^{0}\right)$ of $\mathrm{MO}_{\mathrm{x}}$ can be used as an indication of the bond strength of the metal-oxygen in the oxides, in general and $\Delta \mathrm{H}^{0}$ does not depend on the valence of the metal. Conductivity results of $\mathrm{Sr}_{0.85} \mathrm{Y}_{0.10} \mathrm{Ti}_{0.95} \mathrm{M}_{0.05} \mathrm{O}_{3-\delta}$ and $\mathrm{Sr}_{0.88} \mathrm{Y}_{0.08} \mathrm{Ti}_{0.95} \mathrm{M}_{0.05} \mathrm{O}_{3-\delta}$ as a function of the bonding strength of oxides $\mathrm{V}_{2} \mathrm{O}_{5}, \mathrm{CrO}_{3}, \mathrm{MnO}_{3}, \mathrm{Fe}_{2} \mathrm{O}_{3}, \mathrm{CoO}, \mathrm{NiO}$ and $\mathrm{CuO}$ showed that the less stable $\mathrm{MO}$ bond, easier oxygen forms electronic defects for conduction. Conductivity variation over time at $800{ }^{\circ} \mathrm{C}$ was also evaluated, with $\mathrm{Sr}_{0.85} \mathrm{Y}_{0.10} \mathrm{Ti}_{0.95} \mathrm{Co}_{0.05} \mathrm{O}_{3-\delta}$ having the highest conductivity $\left(17.5 \mathrm{~S} \mathrm{~cm}^{-1}\right)$ after $24 \mathrm{~h}$ of oxidation while in reducing atmospheres $\left(\mathrm{p}_{\mathrm{O} 2}=10^{-19} \mathrm{~atm}\right)$ the maximum conductivity obtained was $45 \mathrm{~S} \mathrm{~cm}^{-1}$. Compounds with the mixed-valence $\mathrm{Co}^{3+}-\mathrm{Co}^{4+}$ and $\mathrm{Mn}^{3+}-\mathrm{Mn}^{4+}$ presented high electrical conductivities.

The hypothesis that $\mathrm{Sr}$ content decreases the number of oxygen vacancies can be explained by Equation 11,58 where there is a deficiency limit $\left(\mathrm{x}_{\mathrm{lim}}\right)$ from which perovskite is no longer able to maintain vacancies and new phases will be formed.

$\mathrm{SrTiO}_{3} \stackrel{\text { Sr removal }}{\rightarrow} \mathrm{Sr}_{1-x} \mathrm{TiO}_{3-x} \stackrel{\text { deffieiency lim it }}{\rightarrow} \mathrm{Sr}_{1-x \lim } \mathrm{Ti}_{1-y} \mathrm{O}_{3-x \lim }+y\left(\mathrm{Ti}_{n} \mathrm{O}_{2 n-1}\right)$

The titanium oxide phases formed when the $\mathrm{Sr}$ content was reduced in reducing atmospheres are called Magnelli phases $\left(\mathrm{Ti}_{n} \mathrm{O}_{2 n-1}\right.$, $4<\mathrm{n}<9$ ). As strontium titanate has high electrical conductivity in reducing atmospheres, it is interesting to investigate the activity of a multiphase system in which there is high electronic conductivity in both phases (magnelli and strontium titanate). XRD results with different proportions of $\mathrm{Sr} / \mathrm{Ti}$ showed that the crystalline structures of cubic perovskite and rutile $\left(\mathrm{TiO}_{2}\right)$ are present and there is high titanate deficiency $(\mathrm{Sr} / \mathrm{Ti} \leq 0.9)$, heated at $1200{ }^{\circ} \mathrm{C}$ for $12 \mathrm{~h}$ in air. The concentration of the rutile phase was reduced by increasing the $\mathrm{Sr} / \mathrm{Ti}$ ratio. In titanates with few deficient A sites $(0.01 \leq \mathrm{x} \leq 0.05)$, the presence of the rutile phase and structures of $\mathrm{Sr}_{2} \mathrm{Ti}_{6} \mathrm{O}_{13}$ and $\mathrm{Sr}_{2} \mathrm{Ti}_{5} \mathrm{O}_{12}$ were observed. Samples calcined in air with $7 \% \mathrm{H}_{2}$ with reduced deficiency at A sites showed pure structure of cubic perovskite $\mathrm{Sr} / \mathrm{Ti} \geq 0.98$, Magnelli phases being possible impurities. TGA curves showed that the titanate and Magnelli phases were completely oxidized between 600 and $800{ }^{\circ} \mathrm{C} .{ }^{58}$

Torabi and Etsell ${ }^{59}$ investigated the Yttrium-doped $\mathrm{SrTiO}_{3}$ (YST), deposited in YSZ, as an alternative material to the conventional sulfur and carbon tolerant anode for SOFC. The three samples were infiltrated four times in two heat treatment steps with air $\left(150{ }^{\circ} \mathrm{C}\right.$ for $5 \mathrm{~min}$ and $350{ }^{\circ} \mathrm{C}$ for $15 \mathrm{~min}$ ). After each infiltration step, the samples were submitted to 3 different types of heat treatments: (a) YST-A was infiltrated four times and treated with air at $900{ }^{\circ} \mathrm{C} / 6 \mathrm{~h}$, (b) YST-H was infiltrated four times and treated with hydrogen at $900{ }^{\circ} \mathrm{C} / 6 \mathrm{~h}$ and (c) YST-AH was first infiltrated twice, followed by treatment with air at $900{ }^{\circ} \mathrm{C} / 6 \mathrm{~h}$. Then it was infiltrated two more times followed by treatment with hydrogen $900{ }^{\circ} \mathrm{C} / 6 \mathrm{~h}$. Results of EIS with three types of symmetrical YST-YSZ cells (Table 2) showed that the ohmic resistance $\left(\mathrm{R}_{0}\right)$ did not vary from one cell to another. However, the non-ohmic resistance showed some differences: an arc at intermediate frequency $(100 \mathrm{kHz}-100 \mathrm{~Hz})$ and an arc at low frequency $(<100 \mathrm{~Hz})$. The first is attributed to the electron-ion transfer processes at the interface $\left(R_{1}\right)$, and the second is attributed to the unloaded transfer processes $\left(\mathrm{R}_{2}\right)$, including surface reactions and gas diffusion in the solid. ${ }^{60}$ Table 2 shows that the processes without load transfer were affected by the different heat treatments. The YST-H sample showed the best electrochemical performance (lower $\mathrm{R}_{1}$ and $\mathrm{R}_{2}$ ) compared to the YST-A and YST-A-H samples.
Table 2. Ohmic and non-ohmic polarization of YST cells infiltrated in YSZ with different treatments

\begin{tabular}{cccc}
\hline Cell & $\mathrm{R}_{0}\left(\Omega \mathrm{cm}^{2}\right)$ & $\mathrm{R}_{1}\left(\Omega \mathrm{cm}^{2}\right)$ & $\mathrm{R}_{2}\left(\Omega \mathrm{cm}^{2}\right)$ \\
\hline YST-A & 0.30 & 0.28 & 8.30 \\
YST-A-H & 0.29 & 0.26 & 2.77 \\
YST-H & 0.29 & 0.20 & 1.99 \\
\hline
\end{tabular}

Many studies have been presented Y-doped $\mathrm{SrTiO}_{3}$ as a potential alternative material for electrical, electrochemical, and chemical applications due to its mixed (ionic and electronic) conduction and its morphological characteristics. ${ }^{61}$

In the work, Zhao et al. ${ }^{62} \mathrm{SrTiO}_{3}$ doped with yttria, deficient at the $\mathrm{A}(\mathrm{Sr})$ site, $\left(\left(\mathrm{Y}_{0.08} \mathrm{Sr}_{0.92}\right)_{1-\mathrm{x}} \mathrm{TiO}_{3-\delta}\right)$ was synthesized by the solid-state reaction. The A deficiency limit was lower than $6 \%(\mathrm{~mol})$ in $5 \% \mathrm{H}_{2}$ in air at $1500{ }^{\circ} \mathrm{C}$. The sinterability of the samples $\left(\left(\mathrm{Y}_{0.08} \mathrm{Sr}_{0.92}\right)_{1-\mathrm{x}} \mathrm{TiO}_{3-\delta}\right)$ decreased with increasing of $\mathrm{x}$ deficiency level. The ionic conductivity of $\left(\left(\mathrm{Y}_{0.08} \mathrm{Sr}_{0.92}\right)_{1-\mathrm{x}} \mathrm{TiO}_{3-\delta}\right)$ decreases, while the electronic conductivity reduced with the number of A deficient sites. Chemical analysis of the defects indicated that the introduction of the deficiency at the A-site results not only an increase in oxygen vacancy concentration, but also in decreasing $\mathrm{Ti}^{3+}$ concentration.

In the work of Huang et al. (2006 (b)), ${ }^{63}$ Yttrium-doped strontium titanate $\left(\mathrm{Y}_{\mathrm{x}} \mathrm{Sr}_{1-\mathrm{x}} \mathrm{TiO}_{3}\right)$ was prepared by the solid-state reaction. The maximum electrical conductivity found was with $\mathrm{x}=0.08,71 \mathrm{~S} \mathrm{~cm}^{-1}$ at $800{ }^{\circ} \mathrm{C}$.

In the work of Rosa Silva et al. ${ }^{64} \mathrm{SrTiO}_{3}$ was synthesized by solid-state reaction method, calcined, and sintered to obtain undoped (ST), 4\% (YST04) and 8\% (YST08) of Y-dopant and as a heterojunction with yttria-stabilized zirconia (YST08/YSZ). The effects of calcination atmosphere and dopant concentration on formation of the perovskite and grain size distribution of the material were investigated. It was observed that calcination under $\mathrm{Ar} / 5 \% \mathrm{H}_{2}$ atmosphere increased the dopant maximum concentration in the $\mathrm{SrTiO}_{3}$ cubic crystal structure when compared to inert atmosphere. When the $\mathrm{Y}$ solubility limit was exceeded, a pyrochlore phase $\mathrm{Y}_{2} \mathrm{Ti}_{2} \mathrm{O}_{7}$ was formed at the intergranular region due to the deficiency of oxygen vacancies, especially in the presence of inert atmosphere. According to Drozdz et al. ${ }^{54}$ the insertion of $\mathrm{Y}_{2} \mathrm{O}_{3}$ in the crystalline structure of $\mathrm{SrTiO}_{3}$ is conducted as shown by the reaction presented in Equation 12. The donated electrons can occupy empty spaces in the conduction band, create small polarons located in the titanium sites, reduce ions from $\mathrm{Ti}^{4+}$ to $\mathrm{Ti}^{3+}$ or they can be associated with oxygen vacancies.

$$
\mathrm{Y}_{2} \mathrm{O}_{3} \stackrel{\mathrm{SrTiO}_{3}}{\rightarrow} 2 \mathrm{Y}_{\mathrm{Sr}}^{\cdot}+2 e^{\prime}+3 \mathrm{O}_{O}^{x}
$$

Thus, in order to replace a $\mathrm{Y}^{3+}$ cation at a $\mathrm{Sr}^{2+}$ site, there must be enough oxygen vacancies to absorb the three oxygen atoms from $\mathrm{Y}_{2} \mathrm{O}_{3}$. In the same work, Drozdz et al. ${ }^{54}$ also showed the effect of the reducing atmosphere on oxygen present in the $\mathrm{SrTiO}_{3}$ structure, as seen in Equation 13. Therefore, when exposing the $\mathrm{SrTiO}_{3}$ structure to a reducing atmosphere, a greater amount of oxygen vacancies appears, and they are necessary for the incorporation of $\mathrm{Y}^{3+}$ in the crystalline structure of the perovskite, thus increasing the solubility of the material for this type of doping.

$$
O_{O}^{x} \stackrel{H_{2}}{\rightarrow} \frac{1}{2} O_{2}+V_{\ddot{O}}+2 e^{\prime}
$$

TGA and DTA curves presented a peak of water desorption and two overlapping peaks of $\mathrm{SrCO}_{3}$ phase change and decomposition. Ceramic microstructure was studied by SEM-EDS and the results showed that $\mathrm{Y}$ incorporation inhibits the grain growth in sintering step, 
reaching a smallest value of grain size in YST08/YSZ heterojunction under $\mathrm{Ar} / 5 \% \mathrm{H}_{2}$ atmosphere. ${ }^{64}$

Curi $^{65}$ developed a one-dimensional and isothermal phenomenological mathematical model of ion transport and electronic transport anode bilayer structures MIEC/electrolyte used in SOFC. Performance simulation results showed that yttriumdoped strontium titanate can replace conventional anode because it reached minimal polarization resistance at $670{ }^{\circ} \mathrm{C}$, which is lower than the electronic conduction temperature of the conventional anode $\mathrm{Ni} / Y S Z$. Furthermore, the decrease in anode thickness, which reduces the ohmic polarization, also increased the charge transfer rates.

\section{Pyrochlore anodes}

Pyrochlores are the only oxides in which simultaneous transformations of order and disorder of cations and anions align the structure. Some crystals have characteristics of allotropy and polymorphism, that is, they exist in more than one crystalline form depending on the conditions of the medium (pressure and temperature). $\mathrm{Cur}^{65}{ }^{65}$ mentioned that the crystalline $\mathrm{Ti}$ and $\mathrm{Zr}$ structures at room temperature are hexagonal $(\mathrm{HC})$ and at temperatures above $883^{\circ} \mathrm{C}$ in the case of $\mathrm{Ti}$ and $872{ }^{\circ} \mathrm{C}$, for $\mathrm{Zr}$, they become body-centered cubic (BCC). For $\mathrm{Ca}$ it is a face-centered cubic (FCC) at room temperature and $\mathrm{BCC}$ at temperatures above $447^{\circ} \mathrm{C}$. This structural change can be explained by the atomic packing factor (APF) and coordination number, which give the metals less energy and stability arrangements. However, HC and FCC crystals have the same APF value $(74 \%)$ and a coordination number of 12 , however, the atomic packing is differentiating them.

Defect pyrochlore oxide powders $\mathrm{ABi}_{2} \mathrm{Ta}_{5} \mathrm{O}_{16}$ in pseudo-binary systems $\mathrm{BiTaO}_{4}-\mathrm{ATa}_{3} \mathrm{O}_{8}(\mathrm{~A}=\mathrm{Na}, \mathrm{Tl})$ were prepared by the solid-state method (Ahmed et al., 2019). ${ }^{66}$ The structural study showed cubic crystal lattice with $F d 3 m$ space group to all oxides. The FTIR and Raman bands observed for these compositions are consistent with the Raman spectra expected for defect pyrochlores, $A B B O^{\prime} \mathrm{O}_{7-\mathrm{x}}$. The morphology of sintering ceramics indicates good densification of the materials. The dielectric constants are in the range of 107-110 with a negative temperature coefficient of permittivity. Dielectric losses of the compound $\mathrm{NaBi}_{2} \mathrm{Ta}_{5} \mathrm{O}_{16}$ presented the maximum values versus temperature and frequency, this phenomenon is related to dielectric relaxations. The activation energy and relaxation time $\tau_{0}$ corresponding these phenomena were found to be $0.16 \mathrm{eV}$ and $0.6 \times 10^{-13} \mathrm{~s}$, respectively. Such dielectric and electrical properties make the compound $\mathrm{NaBi}_{2} \mathrm{Ta}_{5} \mathrm{O}_{16}$ attractive in the electrochemical applications.

In pyrochlore oxides $\left(\mathrm{A}_{2} \mathrm{~B}_{2} \mathrm{O}_{7}\right)$, there are different valence combinations in $\mathrm{A}$ and $\mathrm{B}$ cations, but most of the known pyrochlores, including in the work by Wuensh et al. ${ }^{67}$ the phases contain $\mathrm{A}^{3+}$ and $\mathrm{B}^{4+}$. Among the physical properties of these materials, the high mobility of oxygen ions is attractive for applications in SOFC. ${ }^{68}$ The substitution of species A or B leads to disorder as the substitution reduces the difference between the average radii of the species that occupy these sites. The size difference between the cations can be the driving force for ordering the pyrochlore superstructure. Usually, the replacement of a larger tetravalent cation at the B-site or a smaller trivalent cation at the A-site, or the heating of the phases can lead to some structure disorder, but in the case of pyrochlore oxides, which the strength of the covalent bond is strong, it does not.

In Kaiser et al. ${ }^{69} \mathrm{Sr}_{0.2} \mathrm{Ba}_{0.4} \mathrm{Ti}_{0.2} \mathrm{Nb}_{0.8} \mathrm{O}_{3}$ was investigated as a material with potential for application as SOFC anode with analysis by EIS and DC conductivity in air under partial oxygen pressure variation at $10 \mathrm{~S} \mathrm{~cm}^{-1}\left(\mathrm{p}_{\mathrm{O} 2}=10^{-20} \mathrm{~atm}\right.$ and $\left.930^{\circ} \mathrm{C}\right)$. EIS measurements show a Warburg-like behavior, indicating that the process is limited
Table 3. SOFC Conductivity for different anode materials as function of temperature and atmosphere

\begin{tabular}{|c|c|c|c|c|}
\hline Reference & Anode material & Atmosphere & $\mathrm{T}\left({ }^{\circ} \mathrm{C}\right)$ & $\begin{array}{c}\sigma \\
\left(\mathrm{S} \mathrm{cm}^{-1}\right)\end{array}$ \\
\hline \multirow{2}{*}{16} & $\mathrm{La}_{0.1} \mathrm{Ca}_{0.9} \mathrm{TiO}_{3}$ & $\mathrm{pH}_{2} \mathrm{O} / \mathrm{pH}_{2}=0.01$ & 900 & 50 \\
\hline & $\mathrm{La}_{0.1} \mathrm{Ca}_{0.9} \mathrm{TiO}_{3}$ & Air & & 0.003 \\
\hline \multirow{2}{*}{15} & $\mathrm{La}_{0.4} \mathrm{Ca}_{0.6} \mathrm{Cr}_{0.2} \mathrm{Ti}_{0.8} \mathrm{O}_{3-\delta}$ & $5 \% \mathrm{H}_{2} /$ air & 1000 & 50 \\
\hline & $\mathrm{La}_{0.05} \mathrm{Ca}_{0.95} \mathrm{Cr}_{0.2} \mathrm{Ti}_{0.8} \mathrm{O}_{3-\delta}$ & Air & & 1 \\
\hline \multirow{12}{*}{17} & $\mathrm{Sr}_{2} \mathrm{MgMoO}_{6-\delta}$ & $5 \% \mathrm{H}_{2} /$ air & 800 & 42. \\
\hline & $\mathrm{Sr}_{2} \mathrm{MnMoO}_{6-\delta}$ & & & 5.4 \\
\hline & $\mathrm{Sr}_{2} \mathrm{MgMoO}_{6-\delta}$ & $\mathrm{H}_{2}$ & & 8.6 \\
\hline & $\mathrm{Sr}_{2} \mathrm{MnMoO}_{6-\delta}$ & & & 8.3 \\
\hline & $\mathrm{Sr}_{2} \mathrm{MgMoO}_{6-\delta}$ & $97 \% \mathrm{H}_{2} 3 \% \mathrm{H}_{2} \mathrm{O}$ & & 8.5 \\
\hline & $\mathrm{Sr}_{2} \mathrm{MnMoO}_{6-\delta}$ & & & 8.0 \\
\hline & $\mathrm{Sr}_{2} \mathrm{MgMoO}_{6-\delta}$ & $\mathrm{H}_{2} / \mathrm{H}_{2} \mathrm{~S}$ & & 8.5 \\
\hline & $\mathrm{Sr}_{2} \mathrm{MnMoO}_{6-\delta}$ & & & 7.0 \\
\hline & $\mathrm{Sr}_{2} \mathrm{MgMoO}_{6-\delta}$ & $\mathrm{CH}_{4}$ & & 8.5 \\
\hline & $\mathrm{Sr}_{2} \mathrm{MnMoO}_{6-\delta}$ & & & 11.1 \\
\hline & $\mathrm{Sr}_{2} \mathrm{MgMoO}_{6-\delta}$ & $\begin{array}{c}97 \% \mathrm{CH}_{4} \\
3 \% \mathrm{H}_{2} \mathrm{O}\end{array}$ & & 6.6 \\
\hline & $\mathrm{Sr}_{2} \mathrm{MnMoO}_{6-\delta}$ & & & 10.6 \\
\hline \multirow{10}{*}{18} & $\mathrm{La}_{0.60} \mathrm{TiO}_{2.90}$ & \multirow{10}{*}{$\mathrm{N}_{2}$} & \multirow{10}{*}{150} & $1.30 .10^{-4}$ \\
\hline & $\mathrm{La}_{0.58} \mathrm{TiO}_{2.87}$ & & & $1.10 .10^{-4}$ \\
\hline & $\mathrm{La}_{0.57} \mathrm{TiO}_{2.86}$ & & & $1.00 .10^{-4}$ \\
\hline & $\mathrm{La}_{0.55} \mathrm{TiO}_{2.83}$ & & & $8.25 .10^{-5}$ \\
\hline & $\mathrm{La}_{0.54} \mathrm{TiO}_{2.81}$ & & & $7.35 .10^{-5}$ \\
\hline & $\mathrm{Pr}_{0.60} \mathrm{TiO}_{2.90}$ & & & $1.65 .10^{-5}$ \\
\hline & $\mathrm{Pr}_{0.58} \mathrm{TiO}_{2.87}$ & & & $1.42 .10^{-5}$ \\
\hline & $\mathrm{Pr}_{0.57} \mathrm{TiO}_{2.86}$ & & & $1.27 .10^{-5}$ \\
\hline & $\mathrm{Pr}_{0.55} \mathrm{TiO}_{2.83}$ & & & $1.10 .10^{-5}$ \\
\hline & $\mathrm{Pr}_{0.54} \mathrm{TiO}_{2.81}$ & & & $9.75 .10^{-6}$ \\
\hline 20 & $\mathrm{La}_{0.9} \mathrm{Sr}_{0.1} \mathrm{Ga}_{0.8} \mathrm{Mn}_{0.2} \mathrm{O}_{3}$ & $\mathrm{H}_{2}-4 \%$ air & 900 & 60 \\
\hline \multirow{2}{*}{21} & \multirow{2}{*}{$\mathrm{La}_{0.9} \mathrm{Sr}_{0.1} \mathrm{Ga}_{0.8} \mathrm{Mn}_{0.2} \mathrm{O}_{3}$} & \multirow{2}{*}{ Air } & 700 & 0.08 \\
\hline & & & 800 & 0.1 \\
\hline \multirow{3}{*}{58} & $\mathrm{Sr}_{0.86} \mathrm{Y}_{0.08} \mathrm{TiO}_{3-\delta}$ & & & 82 \\
\hline & $\mathrm{Sr}_{0.88} \mathrm{Y}_{0.08} \mathrm{TiO}_{3-\delta}$ & $\mathrm{pO}_{2}=10^{-19} \mathrm{~atm}$ & 800 & 64 \\
\hline & $\mathrm{Sr}_{0.85} \mathrm{Y}_{0.10} \mathrm{Ti}_{0.95} \mathrm{Co}_{0.05} \mathrm{O}_{3^{-} \delta}$ & & & 45 \\
\hline 58 & $\mathrm{La}_{0.75} \mathrm{Sr}_{0.25} \mathrm{Cr}_{0.5} \mathrm{Mn}_{0.5} \mathrm{O}_{3}$ & $\mathrm{pO}_{2}=10^{-19} \mathrm{~atm}$ & 800 & 45 \\
\hline \multirow{3}{*}{22} & \multirow{3}{*}{$\mathrm{La}_{0.4} \mathrm{Sr}_{0.5} \mathrm{Ti}_{0.6} \mathrm{Fe}_{0.4} \mathrm{O}_{3-\delta}$} & Air & \multirow{3}{*}{900} & 33.6 \\
\hline & & $\begin{array}{l}\mathrm{H}_{2} 97 \% \\
\mathrm{H}_{2} \mathrm{O}\end{array}$ & & 1.7 \\
\hline & & $\begin{array}{c}\mathrm{H}_{2} 10 \% \\
\mathrm{H}_{2} \mathrm{~S} \\
\end{array}$ & & 1.6 \\
\hline \multirow{8}{*}{23} & \multirow{2}{*}{$\mathrm{Sr}_{0.97} \mathrm{Ti}_{0.6} \mathrm{Fe}_{0.4} \mathrm{O}_{3-\delta}$} & & $470-870$ & $11.9 *$ \\
\hline & & & $870-1220$ & $9.35^{*}$ \\
\hline & \multirow{2}{*}{$\mathrm{Sr}_{0.90} \mathrm{Ti}_{0.6} \mathrm{Fe}_{0.4} \mathrm{O}_{3-\delta}$} & & $470-890$ & $11.5^{*}$ \\
\hline & & & $440-800$ & $8.2 *$ \\
\hline & \multirow{2}{*}{$\mathrm{La}_{0.4} \mathrm{Sr}_{0.5} \mathrm{Ti}_{0.6} \mathrm{Fe}_{0.4} \mathrm{O}_{3-\delta}$} & & $890-1220$ & $12.3^{*}$ \\
\hline & & & $840-1060$ & $8.54 *$ \\
\hline & \multirow{2}{*}{$\mathrm{Sr}_{0.97} \mathrm{Ti}_{0.6} \mathrm{Fe}_{0.4} \mathrm{O}_{3-\delta}$} & & $890-1020$ & $14.2 * *$ \\
\hline & & & 970-1020 & $13^{* *}$ \\
\hline \multirow{2}{*}{25} & \multirow{2}{*}{$\mathrm{La}_{4} \mathrm{Sr}_{8} \mathrm{Ti}_{11} \mathrm{Ga}_{0,5} \mathrm{Mn}_{0.5} \mathrm{O}_{37.5}$} & Air & \multirow{2}{*}{900} & 0.0004 \\
\hline & & $\mathrm{pO}_{2}=10^{-15} \mathrm{~atm}$ & & 0.5 \\
\hline 3 & WC & & 25 & $0.52 .10^{5 *}$ \\
\hline 69 & $\mathrm{Sr}_{0.6} \mathrm{Ba}_{0.4} \mathrm{Ti}_{0.2} \mathrm{Nb}_{0.8} \mathrm{O}_{3}$ & & 930 & $10 *$ \\
\hline 70 & $\begin{array}{l}\mathrm{Gd}_{2}\left(\mathrm{Ti}_{0.3} \mathrm{Mo}_{0.7}\right)_{2} \mathrm{O}_{7} \\
\left(\mathrm{Gd}_{0.9} \mathrm{Ca}_{0.1}\right)_{2} \mathrm{Ti}_{2} \mathrm{O}_{7} \\
\end{array}$ & & 1000 & $5.10^{-2 * *}$ \\
\hline 71 & $\left.\mathrm{Gd}_{2} \mathrm{Ti}_{2} \mathrm{Mo}_{2}\right)_{2} \mathrm{O}_{7}$ & & 1000 & 70 \\
\hline & $\mathrm{U}_{2}\left(1 \mathrm{H}_{0.5} \mathrm{IIO}_{0.5}\right)_{2} \mathrm{U}_{7}$ & & 1000 & 25 \\
\hline
\end{tabular}

* electronic conductivity, ** ionic conductivity. 
Table 4. SOFC power densities for different anode materials as a function of temperature and atmosphere

\begin{tabular}{|c|c|c|c|c|c|}
\hline Reference & Anode & Cathode & Fuel & $\mathrm{T}\left({ }^{\circ} \mathrm{C}\right)$ & $\mathrm{P}_{\text {max }}\left(\mathrm{mW} \mathrm{cm}{ }^{-2}\right)$ \\
\hline $72 *$ & $\mathrm{Ni}-\mathrm{Cu}$ & $\mathrm{LiNiO}_{2}$ & $\begin{array}{c}\mathrm{MetOH} \\
\mathrm{EtOH}\end{array}$ & 600 & $\begin{array}{l}330 \\
330 \\
\end{array}$ \\
\hline $73 *$ & $\mathrm{Ni}-\mathrm{Cu}$ & $\mathrm{LiNiO}_{2}$ & Biogas & $\begin{array}{l}600 \\
800\end{array}$ & $\begin{array}{l}100 \\
700 \\
\end{array}$ \\
\hline $74 *$ & $\begin{array}{l}\mathrm{Ni}-\mathrm{Zn} \\
\mathrm{Ni}-\mathrm{Sn} \\
\mathrm{Ni}-\mathrm{Fe}\end{array}$ & $\mathrm{LiNiO}_{2}$ & $\mathrm{EtOH}$ & 600 & $\begin{array}{l}353 \\
306 \\
223\end{array}$ \\
\hline $75^{*}$ & $\mathrm{LiNiO}_{2}$ & $\mathrm{LiNiO}_{2}$ & MetOH & 550 & 512 \\
\hline $75^{*}$ & $\mathrm{Ni}-\mathrm{Cu}-\mathrm{Zn}$ & $\mathrm{LiNiO}_{2}$ & $\mathrm{MetOH}$ & $\begin{array}{l}600 \\
500\end{array}$ & $\begin{array}{l}603 \\
431 \\
\end{array}$ \\
\hline $76^{*}$ & $\mathrm{ZnO} / \mathrm{NiO}$ & $\mathrm{ZnO} / \mathrm{NiO}$ & $\mathrm{H}_{2}$ & $\begin{array}{l}520 \\
500 \\
480 \\
\end{array}$ & $\begin{array}{c}1257 \\
1107 \\
840 \\
\end{array}$ \\
\hline $77 *$ & $\mathrm{Li}_{0.2} \mathrm{Ni}_{0.7} \mathrm{Cu}_{0.1} \mathrm{O} / \mathrm{SDC}-\mathrm{Na}_{2} \mathrm{CO}_{3}$ & $\mathrm{Li}_{0.2} \mathrm{Ni}_{0.7} \mathrm{Cu}_{0.1} \mathrm{O} / \mathrm{SDC}-\mathrm{Na}_{2} \mathrm{CO}_{3}$ & $\begin{array}{c}\text { Glycerol } \\
\text { Bio-EtOH }\end{array}$ & 580 & $\begin{array}{l}215 \\
148 \\
\end{array}$ \\
\hline 78 apud $79 *$ & LiCuNiZnO & & Bio-EtOH & 570 & 584 \\
\hline $80 *$ & C-MO-Ce-O & & MetOH & 560 & 250 \\
\hline $81 *$ & $\mathrm{Zn}-\mathrm{Ni}-\mathrm{Cu}$ & $\mathrm{CuNiO}_{\mathrm{x}}-\mathrm{ZnO}$ & MetOH & 580 & 500 \\
\hline $82 *$ & $\mathrm{C}-(\mathrm{Ni}, \mathrm{Cu}, \mathrm{Co}) \mathrm{O}$ & $\mathrm{NiO}$ & $\mathrm{MetOH} / 3 \% \mathrm{H}_{2} \mathrm{O}$ & 550 & 258 \\
\hline \multirow[t]{2}{*}{$83 \#$} & \multirow[t]{2}{*}{ Ru-Ni-GDC } & \multirow[t]{2}{*}{$\mathrm{Sm}_{0.5} \mathrm{Sr}_{0.5} \mathrm{CoO}_{3}$} & $\begin{array}{c}\text { Dry } \mathrm{CH}_{4} \\
\text { Humidified } \mathrm{CH}_{4} \\
\mathrm{C}_{2} \\
\mathrm{C}_{3}\end{array}$ & 600 & $\begin{array}{l}750 \\
769 \\
716 \\
648 \\
769 \\
\end{array}$ \\
\hline & & & $\mathrm{H}_{2}$ & $\begin{array}{l}550 \\
525 \\
500\end{array}$ & $\begin{array}{l}511 \\
334 \\
246\end{array}$ \\
\hline \multirow{3}{*}{84} & $\begin{array}{c}\mathrm{Cu}-\mathrm{CeO}_{2} \mathrm{ScSZ} \\
\mathrm{Cu}\left(\mathrm{NO}_{3}\right)_{2} \mathrm{Ce}\left(\mathrm{NO}_{3}\right)_{3} \\
21.5 \% \text { w/w Cu } \\
8.5 \% \text { w/w CeO }\end{array}$ & $\left(\mathrm{Pr}_{0.7} \mathrm{Ca} 0.3\right)_{0.9} \mathrm{MnO}_{3}$ & $\mathrm{H}_{2}$ & 800 & 372 \\
\hline & $\begin{array}{l}21.5 \% \mathrm{w} / \mathrm{w} \mathrm{Cu} \\
8.5 \% \mathrm{w} / \mathrm{w} \mathrm{CeO}_{2} \\
\end{array}$ & & & $\begin{array}{l}750 \\
700 \\
\end{array}$ & $\begin{array}{l}234 \\
130 \\
\end{array}$ \\
\hline & $\begin{array}{c}21.5 \% \mathrm{w} / \mathrm{w} \mathrm{Cu} \\
8.5 \% \mathrm{w} / \mathrm{w} \mathrm{CeO} \\
\end{array}$ & & $\mathrm{EtOH}+\mathrm{H}_{2} \mathrm{O}$ & $\begin{array}{l}800 \\
750 \\
\end{array}$ & $\begin{array}{l}222 \\
139 \\
\end{array}$ \\
\hline $21 \Delta$ & $\mathrm{La}_{0.9} \mathrm{Sr}_{0.1} \mathrm{Ga}_{0.8} \mathrm{Mn}_{0.2} \mathrm{O}_{3}$ & LSC & $\mathrm{CH}_{4}$ & 800 & 88 \\
\hline $58 \bullet$ & $\mathrm{Sr}_{0.86} \mathrm{Y}_{0.08} \mathrm{TiO}_{3-\delta}$ & LSGM & $7 \% \mathrm{H}_{2}$ & 900 & 58 \\
\hline \multirow[t]{2}{*}{84} & $\begin{array}{c}20 \% \text { w/w } \mathrm{Cu} 10 \% \\
\text { w/w } \mathrm{CeO}_{2} \\
18 \% \text { w/w Cu } \\
12 \% \text { w/w } \mathrm{CeO}_{2}\end{array}$ & & \multirow[t]{2}{*}{$\mathrm{H}_{2}$} & $\begin{array}{l}800 \\
750 \\
700 \\
800 \\
750 \\
700 \\
800\end{array}$ & $\begin{array}{l}322 \\
220 \\
122 \\
310 \\
205 \\
122 \\
323\end{array}$ \\
\hline & $\begin{array}{c}15 \% \mathrm{w} / \mathrm{w} \mathrm{Cu} \\
15 \% \mathrm{w} / \mathrm{w} \mathrm{CeO}_{2} \\
\end{array}$ & $\left(\mathrm{Pr}_{0.7} \mathrm{Ca} 0.3\right)_{0.9} \mathrm{MnO}_{3}$ & & $\begin{array}{l}750 \\
700 \\
\end{array}$ & $\begin{array}{l}201 \\
106 \\
\end{array}$ \\
\hline 52 & CG4 & LSM & $\begin{array}{c}1.7 \% \mathrm{CH}_{4+} 3 \% \mathrm{H}_{2} \mathrm{O} \\
6.7 \% \mathrm{CH}_{4}+3 \% \mathrm{H}_{2} \mathrm{O} \\
33 \% \mathrm{CH}_{4}+3 \% \mathrm{H}_{2} \mathrm{O} \\
4.9 \% \mathrm{CH}_{4}+2 \% \mathrm{H}_{2+} 3 \% \mathrm{H}_{2} \mathrm{O}\end{array}$ & 1000 & $\begin{array}{c}13.3 \\
47 \\
83.9 \\
178.5 \\
\end{array}$ \\
\hline $25 \bullet$ & $\mathrm{La}_{4} \mathrm{Sr}_{8} \mathrm{Ti}_{11} \mathrm{Mn}_{0.5} \mathrm{Ga}_{0.5} \mathrm{O}_{3,5}$ & LSM & $\begin{array}{c}\mathrm{H}_{2} \\
\mathrm{CH}_{4} \\
\end{array}$ & 950 & $\begin{array}{l}500 \\
350 \\
\end{array}$ \\
\hline \multirow{5}{*}{$17 \bullet$} & & & $\mathrm{H}_{2}$ & $\begin{array}{l}800 \\
700 \\
650 \\
\end{array}$ & $\begin{array}{l}968 \\
838 \\
450 \\
\end{array}$ \\
\hline & $\mathrm{Sr}_{2} \mathrm{Mg}_{0.8} \mathrm{Mn}_{0.2} \mathrm{MoO}_{6-\delta}$ & & $\begin{array}{c}\mathrm{H}_{2} \\
\mathrm{H}_{2} / \mathrm{H}_{2} \mathrm{~S} \\
\end{array}$ & \multirow{4}{*}{800} & $\begin{array}{l}700 \\
660 \\
\end{array}$ \\
\hline & $\mathrm{Sr}_{2} \mathrm{Mg}_{0.5} \mathrm{Mn}_{0.5} \mathrm{MoO}_{6-\delta}$ & & $\begin{array}{c}\mathrm{H}_{2} \\
\mathrm{H}_{2} / \mathrm{H}_{2} \mathrm{~S} \\
\end{array}$ & & $\begin{array}{l}651 \\
577 \\
\end{array}$ \\
\hline & $\mathrm{Sr}_{2} \mathrm{MnMoO}_{6-\delta}$ & & $\begin{array}{c}\mathrm{H}_{2} \\
\mathrm{H}_{2} / \mathrm{H}_{2} \mathrm{~S}\end{array}$ & & $\begin{array}{l}660 \\
591\end{array}$ \\
\hline & $\mathrm{Sr}_{2} \mathrm{Mg}_{0.9} \mathrm{Cr}_{0.1} \mathrm{MoO}_{6-\delta}$ & & $\begin{array}{c}\mathrm{H}_{2} \\
\mathrm{H}_{2} / \mathrm{H}_{2} \mathrm{~S}\end{array}$ & & $\begin{array}{l}790 \\
610\end{array}$ \\
\hline \multirow[b]{2}{*}{$59 \bullet$} & \multirow[b]{2}{*}{$\mathrm{Sr}_{0.88} \mathrm{Y}_{0.08} \mathrm{TiO}_{3}$} & \multirow[b]{2}{*}{ LSM } & $\mathrm{H}_{2}$ dry & \multirow[b]{2}{*}{850} & 95 \\
\hline & & & $\begin{array}{c}\mathrm{CH}_{4} \\
0.5 \% \mathrm{H}_{2} \mathrm{~S} \\
\end{array}$ & & 37 \\
\hline
\end{tabular}


by diffusion. This diffusion limitation may be due to the low ionic conductivity of the oxide or to the layer formed during the sintering of the anode on the electrolyte at temperatures above $1250{ }^{\circ} \mathrm{C}$.

In Kramer and Tuller ${ }^{70}$ titanates conducting oxygen ions $\left(\mathrm{Gd}_{1-\mathrm{x}} \mathrm{A}_{\mathrm{x}}\right)_{2}\left(\mathrm{Ti}_{1-\mathrm{y}} \mathrm{B}_{\mathrm{y}}\right)_{2} \mathrm{O}_{7}$ were prepared by the Pechini method. ${ }^{19}$ Electron acceptors of sites $\mathrm{A}(\mathrm{Ca})$ and $\mathrm{B}(\mathrm{Al})$ were incorporated into the $\mathrm{A}_{2} \mathrm{~B}_{2} \mathrm{O}_{7}$ structure network. For $\mathrm{Gd}_{2}\left(\mathrm{Ti}_{1-\mathrm{y}} \mathrm{Al}_{\mathrm{y}}\right)_{2} \mathrm{O}_{7}$ the $\mathrm{Al}(0<\mathrm{y}<1)$ solubility was determined using lattice constant measurements by $\mathrm{X}$-ray diffraction, as $\mathrm{Al}^{3+}$ is less than $\mathrm{Ti}^{4+}$ lattice parameter decreased up to $0.002 \AA$. For $y>0.01$ there was no apparent variation in the lattice constant, thus it was concluded that the limit of solubility of $\mathrm{Al}^{+3}$ in $\mathrm{Gd}_{2}\left(\mathrm{Ti}_{1-\mathrm{y}} \mathrm{Al}_{\mathrm{y}}\right)_{2} \mathrm{O}_{7}$ is for $\mathrm{y}<0.01$. Total electrical conductivity measured in the bulk $(\sigma)$ of $\left(\mathrm{Gd}_{1-\mathrm{x}} \mathrm{Ca}_{\mathrm{x}}\right)_{2} \mathrm{Ti}_{2} \mathrm{O}_{7}, \mathrm{x}=0.0025,0.02,0.05$ and 0.10 as a function of the oxygen partial pressure and temperatures $\mathrm{T}=800,850,900,950,1000,1050$ and $1100{ }^{\circ} \mathrm{C}$ showed that for all cases $\left(\mathrm{x}\right.$ and $\mathrm{T}$ ) for $\mathrm{p}_{\mathrm{O} 2} \geq 10^{-6} \sigma$ is independent of the oxygen partial pressure, and for $\mathrm{x}=0.005$ and 0.10 and $\mathrm{T} \leq 900 \sigma$ is also independent of the oxygen partial pressure. Ionic conductivity measurements $\left(_{\sigma i}\right)$ of $\left(\mathrm{Gd}_{1-\mathrm{x}} \mathrm{Ca}_{\mathrm{x}}\right)_{2} \mathrm{Ti}_{2} \mathrm{O}_{7}$ showed that the greater $\mathrm{x}$, and the greater the temperature, the greater the $\sigma_{i}$, in addition, the greater $\mathrm{x}$ the smaller the variation in $\sigma_{i}$ as a function of temperature. Total electrical conductivity measurements in the $\mathrm{Gd}_{2}\left(\mathrm{Ti}_{0.99} \mathrm{Al}_{0.01}\right)_{2} \mathrm{O}_{7}$ bulk as a function of the oxygen partial pressure showed that for $\mathrm{pO}_{2} \geq 10^{-10} \sigma$ is independent of the oxygen partial pressure for all temperatures. At $1000{ }^{\circ} \mathrm{C}, \sigma_{\mathrm{i}}\left(\mathrm{Gd}_{1-\mathrm{x}} \mathrm{Ca}_{\mathrm{x}}\right)_{2} \mathrm{Ti}_{2} \mathrm{O}_{7}$ increased with the increase of $\mathrm{x}$ and practically declined with an increase of $\mathrm{y}$ in $\mathrm{Gd}_{2}\left(\mathrm{Ti}_{1-\mathrm{y}} \mathrm{Al}_{\mathrm{y}}\right)_{2} \mathrm{O}_{7}$. This result is consistent with the expected since the introduction of accepting impurities $\mathrm{Ca}^{2+}$ and $\mathrm{Al}^{3+}$ results in the generation of compensating charges for oxygen vacancies. However, the conductivity behavior is slightly different from the linear dependence predicted by the models proposed in the article.

Table 3 summarizes main studies in the literature on electrical conductivity (electronic + ionic) of anodic materials with respective operation temperature and measurement atmosphere (oxidizing or reducing atmosphere). Although there are other anodic materials, such as fluorite and carbide anodes, those were not the focus of this work.

In Table 4, there is a summary of the SOFC power densities for different anode materials, operating temperature, and fuel. Comparing the same anodic material, using the same fuel and the same cathode, in all cases the SOFCs showed higher power density at higher temperatures. Increasing the $\mathrm{CH}_{4}$ concentration increases the SOFC power density, applying CG4 as an anode and LSM as the cathode. In studies that analyzed the influence of the fuel, SOFCs with anodes powered by pure $\mathrm{H}_{2}$ tended to present a higher power density than those powered by hydrogen mixture, $\mathrm{H}_{2} / \mathrm{H}_{2} \mathrm{~S}$ or other fuels $\left(\mathrm{CH}_{4}\right.$, $\mathrm{C} 2, \mathrm{C} 3$, and $\mathrm{EtOH})$. The infiltration of the WC anode increased the power density compared to the conventional WC anode for the same operating temperature.

\section{CONCLUSIONS}

In this work, the authors had the approach of reviewing a large number of published works about materials applied to SOFC anodes. First, we concluded that the currently used material composed by a cermet of $\mathrm{Ni} / \mathrm{YSZ}$ is not applicable to the new requirements such as the feed with other types of fuels and temperature operation. Subsequently, different types of promissory candidates were discussed, concluding that perovskite compounds are structures with great potential for this kind of application once they are stable under a reducing atmosphere and can be easily synthesized. The major advantage of perovskite anodes is the possibility of changing the physical-chemical characteristics (such as electronic/ionic conductivity and thermal expansion) through doping processes. Many different types of cations can be used as dopants in the A and $\mathrm{B}$ sites of the compounds, generating different semiconductors with distinct redox properties and electrocatalytic activity. Among those candidates, the material with mixed, ionic and electronic conductivity consisted by yttrium doped- $\mathrm{SrTiO}_{3}$ stands out as a promising candidate as it can be operated with hydrocarbons fuels (once it does not catalyze the breakage of carbon bonds) at lower temperatures when compared to the operation with $\mathrm{Ni} / \mathrm{YSZ}$ anodes. These structures showed a satisfactory performance regarding its conductivity, mainly when doped with $8 \%$ of the Y cation. However, at this concentration, the solubility limit of the dopant is reached and a secondary phase of pyrochlore is formed, this phase presents an electric insulating character. Hence, it was concluded that the presence of a reducing agent in the calcination atmosphere decreases this insulating phase concentration, improving conductivity. Although the research about adequate materials for SOFC anode is advanced and satisfactory, there are still many challenges in the future such as a significant reduction in the operation temperature $\left(300-600^{\circ} \mathrm{C}\right)$, a deeper understanding on the reaction mechanisms of generation and degradation, and constant optimization of electrodes morphology to improve efficiency.

\section{ACKNOWLEDGEMENTS}

The research leading to these results has received funding from the Coordination for the Improvement of Higher Education Personnel (CAPES), Finance Code 001, The Brazilian National Council for Scientific and Technological Development (CNPq) and The Electrical Energy Research Center (Cepel/Eletrobrás).

\section{REFERENCES}

1. Fiuza, R. P.; Silva, M. A.; Pontes, L. A. M.; Teixeira, L. S. G.; Boaventura, J. S.; Quim. Nova 2012, 35, 1635.

2. Amado, R. S.; Malta, L. F. B.;Garrido, F. M. S.; Medeiros, M. E.; Quim. Nova 2007, 30, 189.

3. Torabi, A., Etsell, T. H.; J. Power Sources 2012, 212, 47.

4. Curi, M. O.; Silva, E. R.; Secchi, A. R.; Furtado, J. G. de M.; Ferraz, H. C.; XXI Congresso Brasileiro de Engenharia Química, Fortaleza, Brasil, 2016.

5. Tarôco, H. A.; Santos, J. A. F.; Domingues, R. Z.; Matencio, T. In Ceramic Materials for Solid Oxide Fuel Cells; Sikalidis, C., ed.; InTech: London, 2011, cap. 19.

6. Matsuzaki, Y.; Yasuda, I.; Solid State Ionics 2000, 132, 261.

7. Lussier, A.;Sofie, S. W.; Dvorak, J.; Idzerda, Y. U.; Int. J. Hydrogen Energy 2008, 33, 3945.

8. Flores, J.A.; Rodríguez, L. A.; Revista Mexicana de Física 2013, 59, 66.

9. Sun, C.; Stimming, U.; J. Power Sources 2007, 171, 247.

10. Curi, M. O.; Dissertação de Mestrado, Universidade Federal do Rio de Janeiro, Brasil, 2011.

11. Magalhães, R. S.; Junior, W. D. M.; Souza, A. E.; Teixeira, S. R.; Li, S. M.; Longo, E.; Quim. Nova 2017, 40, 166.

12. Meulenberg, W. A.; Ivanova, M. A.; Serra, J. M.; Roitsch, S. In Advanced Membrane Science and Technology for Sustainable Energy and Environmental Applications; Basile A., Nunes, S. P., eds.; Woodhead Publishing Limited: Cambridge, 2011, cap. 17.

13. Raphael, E.; Silva, M. N.;Szostak, R.; Schiavon, M. A.; Nogueira, A. N.; Quim. Nova 2018, 41, 61.

14. Yang, L.; Dacek, S. T.; Ceder, G.; Phys. Rev. B 2014, 90, 54102.

15. Vashook, V.; Vasylechko, L.; Knapp, M.; J. Alloys Compd. 2002, 354, 13.

16. Vashook, V.; Vasylechko, L.; Ullmann, L.H.; Guth, U.; Solid State Ionics 2003, 158,263 
17. Huang, H.Y.; Dass, R. I.; Xing, X. L.; Goodenough, J. B.; Science 2006 312, 254.

18. Lepe, F. J.; Fernandez-Uurban, J.; F.; Mestres, L.;Martínez-Sarrión, M. L.; J. Power Sources 2005, 151, 74.

19. Pechini, M. P.; US pat. 3,330, 697, 1967.

20. Pudmich, G.; Boukamp, B. A.; Gonzalez, M. C.; Solid State Ionics 2000, 135, 433.

21. Chen, F.; Liu, M..; J. Solid State Electrochem. 1998, 3, 7.

22. Zha, S.; Tsang, P.; Cheng, Z. J.; Liu, M.; J. Solid State Chem. 2005, 178, 1844.

23. Fagg, D. P.;Kharton, V. V.; Kovalevsky, A.V.; Naumovich, E. N.; Frade, J. R.; J. Eur. Ceram. Soc. 2001, 21, 1831.

24. Kharton, V. V.; Kovalevsky, A. V.; Viskup, A. P.; Figueiredo, F. M.; Frade, J. R.; Yaremchenko, A. A.; Naumovich, E. N.; Solid State Ionics 2000, 128, 117.

25. Ruiz-Morales, J. C..; Canales-Vázquez, J.; Savaniu, C.; Marrero-López, D.; Nature 2006, 439, 568.

26. Vernoux, P.; Guillodo, M.; Fouletier, J., Hammou, A.; Solid State Ionics. 2000, 135, 425.

27. Vernoux, P.; Djurado, E.; Guillodo, M.; J. Am. Ceram. Soc. 2001, 84, 2289.

28. Sfeir, J.; J. Power Sources 2003, 118, 276.

29. Neagu, D.; Irvine, J. D. S. In Comprehensive Inorganic Chemistry II; Reedijk, J., Poeppelmeier, K., eds.; Elsevier: Amsterdam, 2013, cap. 4.15 .

30. Ma, Q.; Iwanschitz, B.; Dashjav, E.; Baumann, S.; Sebold, D.; Raj, I. A.; Mai, A.; Tietz, F.; J. Power Sources 2015, 279, 678.

31. Chen, C.; Zhang, T.; Donelson, R.; Tan, T. T.; Li, S.; J. Alloys Compd. 2015, 629, 49 .

32. Marques, A. C.; Tese de Doutorado, Faculdade de Ciências da Universidade de Lisboa, Portugal, 2009.

33. Muhamad, N. F.; Osman, R. A. M.; Idris, M. S.; Yasin, M. N. M.; EPJ Web of Conferences 2017, 162, 1052.

34. Suwanwong, S.; Eknapakul, T.; Rattanachai, Y.;Masingboon, C.; Rattanasuporn, S.; Pattanakun, R.; Nakajima, H.; King, P.; Hodak, S. K.; Meevasana, W.; Appl. Surf. Sci. 2015, 355, 210.

35. Mohamed, E. A.; Moustafa, M. G.; Kashif, I.; J. Non-Cryst. Solids 2018 , 482, 223.

36. Shackelford, J. F. In Ciência dos Materiais; Sousa, A., Pace, M., eds.; Pearson Publishing: London, 2008.

37. Kharton, V. V.; Kovalevsky, A. V.; Viskup, A. P.; Jurado, J. R.; Figueiredo, F. M.; Naumovich, E. N.; Frade, J. R.; J. Solid State Chem. 2001, 156, 437.

38. Flores, J. J. A.;Rodríguez, M. L. A.; Espinosa, G. A.; Vera, J. V. A.; Int. J. Hydrogen Energ. 2018, 44, 12529.

39. Steinsvik, S.; Bugge, R.; Gjonnes, J.; Norby, J. T. T.; J. Phys. Chem. Solids 1997, 6, 969.

40. Kubacki, J.; Kajewski, D.; Goraus, J.; Szot, K.; Koehl, A.; Lenser, C.; Dittmann, R.; Szade, J.; J. Chem. Phys. 2018, 148, 154702.

41. Baker, J. N.; Bowes, P. C.; Long, D. M.; Moballegh, A.; Harris, J .S.; Dickey, E. C.; Irving, D. L.; Appl. Phys. Lett. 2017, 110, 122903.

42. Li, R.; Liu, F.; Zhang, C.; Liu, J.; Zhou, J.; Xu, L.; Ceram. Int. 2019, 45, 21684

43. Morin, F. J.; Oliver, J. R.; Phys. Rev. B 1973, 8, 5847.

44. Zhao, Z.; Gonçalves, R. V.; Barman, S. K.; Willard, E. J.; Byle, E.; Perry, R.; Wu, Z.; Huda, M. N.; Moulé, A. J.; Osterloh, F. E.; Energy Environ. Sci. 2019, 12, 1385.

45. Bowes, P. C.; Baker, J. N.; Irving, D. L.; J. Am. Ceram. Soc. 2019, 00, 1.

46. Smith, H. B.; Holler, W. C.; Gross, M. D.; Solid State Ionics 2011, 192, 383.

47. Zhang, C.; Wang, C. L.; Li, J. C.; Yang, K.; Zhang, Y. F.; Wu, Q. Z.; Mater. Chem. Phys. 2008, 107, 215.

48. Blennow, P.; Hagen, A.; Hansen, K. K., Wallenberg, L. R.; Mogensen,
M.; Solid State Ionics 2008, 179, 2047.

49. Ozdogan, K.; Kahaly, M. U.; Kumar, S. R. S.; Alshareef, H. N.; Schwingenschlögl, J.; J. Appl. Phys. 2012, 111, 054313.

50. Biswas, A.. Li, N.; Jung, M. H.; Lee, Y. W.; Kim, J. S.; Jeong, Y. H.; J. Appl. Phys. 2013, 113, 183711.

51. Hashimoto, S.; Kammer, K.; Larsen, P. H.; Finn, L.; Poulsen, F. W.; Mogensen, M.; Solid State Ionics 2005, 176, 1013.

52. Marina, O. A.; Canfield, N. L.; Stevenson, J. W.; Solid State Ionics 2002, 149, 21.

53. Li, X.; Zhao, H.; Zhou, X; Xu, N.; Xie, Z.; Chen, N.; Int. J. Hydrogen Energy 2010, 35, 7913.

54. Drozdz, E.;Lacz, A., Kolezynzky, A.;Mikula, A.; Mars, K.; Solid State Ionics 2017, 302, 173

55. Shan, K.; Yi, Z.; Scr. Mater. 2015, 107, 119.

56. Chen, C.; Zhang, T.; Donelson, R.; Tan, T. T.; Li, S.; J. Alloys Compd. 2015, 629, 49 .

57. Gao, F.; Zhao, H.; Li, X.; Cheng, Y.; Zhou, X.; Cui, F.; J. Power Sources 2008, 185, 26.

58. Hui, S.; Petric, A.; Mater. Res. Bull. 2002, 37, 1215.

59. Torabi, A.; Etsell, T. H.; J. Power Sources 2013, 225, 51.

60. Tarôco, H. A.;Andrade, S. T. P.;Brant, M. C.; Domingues, R. Z.; Matencio, T.; Quim. Nova 2009, 32, 1297.

61. Rosa Silva, E.; Nicolini, J. V.; Yamauchi Jr., L.; Machado, T. M.;Curi, M.; Furtado, J. G.; Secchi, A. R.; Ferraz; H. C.; Ceram. Int. 2020, 46, 3592.

62. Zhao, H.; Gao, F.; Li, X., Zhang, C.; Zhao, Y.; Solid State Ionics 2009 , 180, 193.

63. Huang, X.; Halei, Z.; Shen, W.; Qiu, W.; Wiu, W.; J. Phys. Chem. Solids 2006, 67, 2609

64. Rosa Silva, E.; Curi,M.; Furtado, J. G.; Secchi, A. R.; Ferraz; H. C.; Ceram. Int. 2019, 45, 9761.

65. Curi, M. O.; Tese de Doutorado, Universidade Federal do Rio de Janeiro, Brasil, 2015.

66. Ahmed, O. A. S.; Bourja, L.; Chagraoui, A.; Tairi, A.; Moussaoui, A.; Oulahyane, H. A.; Manoun, H.; Villain, S.; Heliyon 2019, 5, 1891.

67. Wuensh, B. J.; Eberman, K. W.; Journal of Sedimentary Environments 2000, 52, 19.

68. Pirzada, M.; Grimes, R. W.;Minervini, L.;Maguire, J. F.; Siackafus, K. E.; Solid State Ionics 2001, 140, 201.

69. Kaiser, A.; Bradley, J. L.; Slater, P. R.; Irvine, J. T. S.; Solid State Ionics 2000, 135, 519.

70. Kramer, S.A.; Tuller, H. L.; Solid State Ionics 1995, 82, 15.

71. Porat, O.; Heremans, C.; Tuller, H.L.; Solid State Ionics 1997, 80, 2278.

72. Zhu, B.; J. Power Sources 2001, 93, 82.

73. Zhu, B.; Bai, X. Y.; Chen, G. X.; Yi, W. M.; Bursell, M.; Int. J. Energy Res. 2002, 26, 57.

74. Huang, J.; Xie, F.; Wang, C.; Mao, Z.; Int. J. Hydrogen Energy 2012, 37, 877.

75. Gao, Z.; Raza, R.; Zhu, B.; Mao, Z.; Wang, C.; Liu, Z.; Int. J. Hydrogen Energy 2011, 36, 3984.

76. Raza, R.; Liu, Q.; Nisar, J.; Electrochem. Commun. 2011, 13, 917.

77. Qin, H.; Zhu, Z.; Liu, Q.; Energy Environ. Sci. 2011, 4, 1273.

78. Imaran, S. K.; Raza, R.; Abbas, G.; Zhu, B.; J. Fuel Cell Sci. Technol. 2011, 8,1 .

79. Fan, L.; Wang, C.; Chen, M.; Zhu, B.; J. Power Sources 2013, 234, 154.

80. Feng, B.; Wang, C. Y., Zhu, B.; J. Electrochem. Soc. 2006, $9,80$.

81. Mat, M. D.; Liu, X., Zhu, Z., Zhu, B.; Int. J. Hydrogen Energy 2006, 32, 796.

82. Xu, S.; Niu, X.; Chen, M.; Wang. C.; J. Power Sources 2007, 165, 82.

83. Hibino, T.; Hashimoto, A.; Yano, M.; Suziki, M.; Sano, M.; Electrochim. Acta 2003, 48, 2531.

84. Ye, X. F.; Huan, B.; Wang, S. R.; Wang, Z. R.; Xiong, L., Wen, T. L.; J. Power Sources 2007, 164, 203. 